\title{
Financial Sector Reform After the Crisis: Has Anything Happened?*
}

\author{
Alexander Schäfer ${ }^{\dagger}$ \\ Johannes Gutenberg University Mainz \\ Isabel Schnabel $\ddagger$ \\ Johannes Gutenberg University Mainz, CEPR, and MPI Bonn \\ Beatrice Weder di Mauro ${ }^{\S}$ \\ Johannes Gutenberg University Mainz and CEPR
}

May 24, 2013

\begin{abstract}
*We would like to thank Robert DeYoung, Charles Goodhart, Florian Hett, Steven Ongena, Hans-Eggert Reimers, Björn Richter, and Takashi Yamagata for helpful comments. We also thank the participants of the following workshops and conferences for their comments: Graduate School of Economics at Pompeu Fabra, Annual Meeting of the German Economic Association, Annual Meeting of the German Finance Association, $9^{t h}$ Workshop on Money, Banking, and Financial Markets and the $1^{\text {st }}$ Research Workshop in Financial Economics at JGU Mainz. Excellent research assistance was provided by Victor Bozhinov, Anna Immel, Christoph Sohn, and Stefan Schmidt. We are grateful to NZZ for free access to the NZZ Archive. Financial support from Deutsche Forschungsgemeinschaft through SPP 1578 is gratefully acknowledged.

${ }^{\dagger}$ Corresponding author. Gutenberg School of Management and Economics, Johannes Gutenberg University Mainz, 55099 Mainz, Germany, alexander.schaefer@uni-mainz.de.

${ }^{\ddagger}$ Gutenberg School of Management and Economics, Johannes Gutenberg University Mainz, 55099 Mainz, Germany, isabel.schnabel@uni-mainz.de.

$\S$ Gutenberg School of Management and Economics, Johannes Gutenberg University Mainz, 55099 Mainz, Germany, beatrice.weder@uni-mainz.de. Beatrice Weder di Mauro has been an independent director on the board of UBS since May 2012. The views expressed in this article are those of the author and should not be attributed to UBS.
\end{abstract}




\title{
Financial Sector Reform After the Crisis: Has Anything Happened?
}

\begin{abstract}
We analyze the reaction of stock returns and CDS spreads of banks from Europe and the United States to four major regulatory reforms in the aftermath of the subprime crisis, employing an event study analysis. In contrast to the public perception that nothing has happened, we find that financial markets indeed reacted to the structural reforms enacted at the national level. All reforms succeeded in reducing bail-out expectations, especially for systemic banks. However, banks' profitability was also affected, showing up in lower equity returns. The strongest effects were found for the Dodd-Frank Act (especially the Volcker rule), whereas market reactions to the German restructuring law were small.
\end{abstract}

Keywords: Financial sector reform; financial stability; Dodd-Frank Act; Volcker rule; Vickers reform; German restructuring law; Swiss too-big-to-fail regulation, event study.

JEL-Classification: G21, G28. 


\section{Introduction}

After the near-collapse of large parts of the financial system and unprecedented support measures from the public sector and central banks, the leaders of the G20 agreed on the need for a radical overhaul of the financial system. In the wake of the London summit in March 2009 and the creation of the Financial Stability Board, the supervisory community has been busy proposing, negotiating, and enacting a wide range of new regulations at the international level. ${ }^{1}$ In parallel, several countries embarked on ambitious reforms at the national level, which have produced a set of structural measures, ranging from the prohibitions of activities and a ring-fencing of retail banking to special resolution or capital regimes for systemically important institutions. This high level of regulatory activity contrasts quite starkly with a widespread public perception that nothing major has happened in the financial sector and that reforms have not had any impact. Therefore, it seems only natural to ask whether reforms have had any measurable effects. It also seems natural to address this question to the market rather than the involved and interested parties.

In this paper we investigate the following questions: How have financial markets reacted to different types of regulatory reforms? In particular, have bank equity valuations and the prices of banks' credit risk been affected by regulatory measures? Have some reforms had a larger impact than others? Have different regulatory interventions had differing effects on different types of banks, such as investment and commercial banks, or systemic and non-systemic banks?

To answer these questions we analyze the reaction of equity returns and CDS spreads following major regulatory events of the banking industry during the period from June 2009 till October 2011 within the framework of an event study. We focus on four important national reform streams, namely the Dodd-Frank Act in the United States, the reforms proposed by the Vickers report in the United Kingdom, the restructuring law and bank levy in Germany, and the too-big-to fail regulation in Switzerland. These four reforms typify fundamentally differing approaches to dealing with the weaknesses of the financial system revealed by the financial crisis: a

\footnotetext{
${ }^{1}$ See, e. g., Financial Stability Board (2009) for an overview of the different reform areas and regulatory work streams.
} 
prohibition of risky activities (Volcker rule in the US), a ring-fencing of systemic activities (UK), the establishment of resolution procedures (Germany), and special capital regimes for systemically important banks (Switzerland). ${ }^{2}$ We also take possible spillovers of national announcements on other countries' banking systems into account. Direct or indirect spillovers may occur either because the relative competitive position of banking centers is affected, or because announcements in one country serve as signals of regulatory changes to come in other countries. The choice of the sample period and, in particular, the fact that we cannot extend it beyond 2011 was dictated by the onset of the Euro crisis which increasingly dominated market signals on bank debt and equity. This also precludes the inclusion of more recent reform proposals, such as the Liikanen report (High-Level Expert Group, 2012).

As in any event study, the timing of events is of the essence. The identification of event periods is a particular challenge in studies evaluating regulatory changes (see, e.g., the discussion by Lamdin, 2001). Regulatory reforms are usually discussed over an extended period of time; there are consultations with experts and affected parties, negotiations between political parties and governments, which make a certain outcome more or less likely. Financial market participants are, of course, aware of these procedures even if they happen behind closed doors, and form outcome expectations, which they update regularly. If a financial reform were a completely predictable process, markets would be able to price in the outcome perfectly and the only real event would be the initial announcement of the reform. However, this is not the way the process of negotiating regulatory reforms works. The process produces compromises and surprises, tougher or weaker regulation than initially expected and therefore new information for markets. One crucial question is how to filter out the important events, the "real" news. Ideally, we would like to identify those events where truly new information (about content or probabilities) became available to markets. We use the editorial process of major financial newspapers as a filtering device: a reform measure is classified as an event if it was published as a lead article on the front page of a major newspaper. ${ }^{3}$

\footnotetext{
${ }^{2}$ The Dodd-Frank Act is the most comprehensive reform package of the four analyzed in this paper. While being only one among numerous other regulations, the Volcker rule has caught most of the attention. A more detailed description of the US regulation is found below.

${ }^{3}$ This procedure is common in the literature, see, for example, O'Hara and Shaw (1990) who base the timing of events on the publication date in the Wall Street Journal.
} 
We are excluding the reforms enacted at the international level, most importantly the Basel III reforms. The reason is that the effects of such reforms can hardly be captured by an event-study analysis, for the following reasons. Given the nature of international negotiations where hundreds if not thousands of people are involved, market expectations are constantly updated. As stressed by MacKinlay (1997), event studies are less useful in such a context. Essentially, the event period uncertainty reduces the power of tests to reject the null hypothesis of no effect (Lamdin, 2001). By contrast, the deliberations in a small commission such as the Vickers commission or the commission preparing the Swiss too-big-to fail regulation are more likely to remain confidential, and the publication of the results would thus induce market prices to adjust suddenly to the changed outlook. Therefore these types of events may be better suited if one wants to capture the full effect "on impact." Moreover, international reforms do not impose binding constraints on banks, e.g., because national reforms (such as the Swiss ones) are more demanding or because the will to implement the international agreements is in doubt (such as in the US). ${ }^{4}$

There is a long tradition of evaluating the effects of regulatory events using event studies, going back to Schwert (1981). ${ }^{5}$ A number of earlier studies deal with the effects of regulatory reforms on bank equity valuation. Eyssell and Arshadi (1990) analyze the effects of imposing risk-based capital requirements under Basel I. Spiegel and Yamori (2003) measure the effect of two regulatory reforms in Japan on bank equity values. Some recent studies deal with the support measures in the current financial crisis. Veronesi and Zingales (2010) study the effect of the Paulson Plan on the valuation of banks relative to non-financial firms. Fratianni and Marchionne (2009) consider fiscal support measures in the banking sector during the recent financial crisis. Finally, a number of papers focus on the problem of systemic banks. O'Hara and Shaw (1990) investigate the effect of the US Comptroller of the Currency's announcement in 1984 that some banks were "too big to fail." Ueda and Weder di Mauro (2010) study changes in the implicit state subsidy to large banks in the US and in Europe including both bail-out (like Bear Stearns) and non-bail-out

\footnotetext{
${ }^{4} \mathrm{An}$ earlier version of this paper also included international events. In fact, most international events did not provoke any significant market reactions. Due to the ambiguity in the interpretation of such results, we decided to focus on country-specific reforms in our analysis.

${ }^{5}$ For a discussion of methodological issues in event studies of regulatory events, see Binder (1985) and Lamdin (2001).
} 
events (like Lehman). To our knowledge, we are the first to investigate the four major reform streams in the aftermath of the financial crisis, and their differing impact on market valuations. ${ }^{6}$

Our results reveal that the public perception that nothing has happened after the crisis does not do justice to the various national efforts to stabilize financial systems and contain systemic risk. We find that financial markets indeed reacted to the structural reforms enacted at the national level. The first announcement of the Volcker rule provoked strong reactions in both equity and CDS markets. Interestingly, the effects were not homogeneous across banks: US investment banks experienced a decrease in equity prices and an increase in CDS spreads relative to commercial banks; the same is true for systemic relative to non-systemic banks. The Volcker rule produced spillover effects to banks in the United Kingdom and Switzerland, but not to Germany. The watering down of the initial Volcker rule proposal in subsequent negotiations is also reflected in market prices, but the overall effect remains negative on equity, and positive on CDS. In contrast, the Vickers reform produced only a modest effect on equity prices, but a strong positive effect on CDS spreads. Again, the effect is more pronounced for investment banks and systemic banks. And again, we see a reversal of results when the Vickers reform was postponed, which indirectly supports the effectiveness of the reform. The overall positive effect on CDS spreads remains, however. A very different type of reform, the enactment of the German special resolution regime, generates little reaction in equity prices. However, we do see a response in CDS markets. In fact, systemic banks appear to have been more affected by the reform than non-systemic banks, although the effects are relatively small compared to the effects observed in other countries. Significant market reactions were also observed in response to the Swiss too-big-to-fail regulation, which strongly increased CDS spreads of systemic banks, but affected equity prices only mildly.

Taken together, these results suggest that all four reforms succeeded in lowering bail-out expectations, as reflected in rising CDS spreads, especially for systemically

\footnotetext{
${ }^{6}$ In a follow-up paper to our analysis, Bongini, Di Battista, Nieri, and Pelagatti (2012) analyze the market reactions to events regarding the regulation of systemically important financial institutions (SIFIs). Their results show that markets hardly reacted to such events, similar to our previous results on international reforms.
} 
important financial institutions. Equity prices were most strongly affected by the announcement of the Volcker rule, both directly (in the US) and indirectly (through spillover effects). This can be explained by the reduction in profitability if banks have to spin off profitable activities, such as trading and swap desk. The heterogeneity of market reactions, which can plausibly be linked to the characteristics of the respective reforms, strengthens the credibility of results. The effects are also quantitatively important. The biggest effects are found for the Dodd-Frank Act, most notably the Volcker Rule. The smallest effects are found for the German restructuring law, which may lack effectiveness due to its inability to deal with the failures of large cross-border banks. This points towards a general shortcoming of reforms carried out at the national level, namely their lack of international coordination, which may lead to regulatory arbitrage or limited effectiveness, as in the German case. It remains to be seen in the longer run which type of reform proves to be most successful and whether the different nations will be able to agree on a harmonization of structural reforms, over and above the common rules on capital requirements under Basel III.

The paper is organized as follows. In Section 2, we characterize the different types of reforms analyzed below and develop a number of predictions regarding their expected effects on equity valuations and CDS spreads. In Section 3, we describe our procedure of identifying relevant regulatory events and present the data set as well as the employed estimation and testing procedures. Section 4 contains our estimation results. For each financial reform, we discuss the effects on stock returns and CDS spreads, and test for heterogeneous effects with respect to business models (investment vs. commercial banks) and systemic importance. In the concluding Section 5, we discuss the implications of our research for economic policy.

\section{Financial Sector Reforms and Market Valuations}

As a first step, we describe the salient features of the reforms under study. Then we derive predictions regarding the expected effects of the reform packages on equity returns and CDS spreads. 


\subsection{Typology of Reform Approaches}

In this study, we focus on the four major structural reforms conducted at the national level in the following countries: the United States, the United Kingdom, Germany, and Switzerland. Interestingly, the reform packages differ fundamentally in their approaches of dealing with systemic risk in the banking sector.

The most notable component of the reform package in the United States is the Volcker rule, which restricts banks' business models by prohibiting certain activities. $^{7}$ In the spirit of the Glass-Steagall Act of 1933, the Dodd-Franck Act limits proprietary trading and investments in hedge funds and private equity. By prohibiting allegedly risky activities, the Volcker rule hopes to reduce the volatility of bank returns and thereby reduce the probability of bank failure. At the same time, it reduces potential diversification benefits between different types of businesses. ${ }^{8}$ One critical issue is how to distinguish prohibited activities from admissible ones, such as market making and hedging. The Dodd-Frank reform package also encompasses rules to tackle the too-big-to-fail problem. Specifically, large financial institutions will be subject to enhanced prudential regulation by the Federal Reserve Board, including the requirement to provide resolution plans (also known as living wills) to alleviate the winding up of an institution in case of failure. Moreover, the DoddFrank Act establishes the Financial Stability Oversight Council (FSOC), which is to identify potential threats to systemic stability.

The most important element of the Vickers reform in the United Kingdom is the ring-fencing approach, which aims at protecting the deposit-taking business from spillovers from investment banking activities in times of distress. ${ }^{9}$ The intention is to split banks into legally separated ring-fenced and non-ring-fenced units. The ring-fenced unit is to encompass the systemically important business (most impor-

${ }^{7}$ The 848 pages of regulation contain numerous other rules and regulation (see Dodd-Frank Act, 2010). For the sake of clarity, we concentrate on the most important ones.

${ }^{8}$ The empirical evidence indeed points towards higher risk of banks who also carry out noninterest income activities (see, e.g., Lepetit, Nys, Rous, and Tarazi, 2008; Demirgüç-Kunt and Huizinga, 2010; Chow and Surti, 2011). Non-interest banking activities have also been shown to raise banks' exposure to systemic risk (De Jonghe, 2010). The evidence of potential diversification benefits from combining traditional and non-traditional banking activities is mixed (see Stiroh, 2006; Baele, De Jonghe, and Vander Vennet, 2007).

${ }^{9}$ See United Kingdom Independent Commission on Banking (2011). 
tantly, deposit-taking), but is prohibited from conducting non-traditional banking activities. The ring-fencing approach raises the resolvability of the investment bank arm and fosters the implicit guarantee of the deposit-taking arm, which is to be countered by higher capital requirements. ${ }^{10}$ The approach retains some diversification benefits, but only in one direction as capital flows from the deposit to the investment arm are restricted. In addition, banks are obliged to write living wills in order to assure an orderly liquidation process. In contrast to the Volcker rule, which can rather easily be implemented, the Vickers reform requires a costly and legally demanding reorganization of financial institutions. Moreover, crucial issues such as the treatment of globally operating institutions remain unresolved.

The reform package in Germany focuses on bank resolution. The new restructuring law intends to facilitate the resolution of failing banks by transferring the systemically relevant part of a failing institution to a bridge bank and subjecting the remaining part to insolvency proceedings. ${ }^{11}$ In contrast to the Vickers approach, the restructuring law does not prescribe a legal separation of different businesses, and hence a reorganization, before failure. The law is accompanied by the establishment of a restructuring fund financed by a bank tax to ensure that the costs of future crises are borne by the financial sector. The tax base consists of uninsured bank debt, and the tax rate increases in the tax base, ranging from two to four basis points. Hence, larger banks have to pay higher tax rates than smaller ones, which is meant to account for differences in the systemic importance of banks. Again the major unresolved issue is the resolution of cross-border banks. Moreover, it remains unclear whether it will be possible to restructure a bank within days if no legal separation is required ex ante. Finally, the systemic component of the bank tax is rather small, and non-bank institutions are not covered.

The reforms in Switzerland focus on the too-big-to-fail problem. This issue is particularly pressing in Switzerland because the Swiss banking sector is dominated by two very large banks. The new too-big-to-fail regulation sharply increases capital

\footnotetext{
${ }^{10}$ Lóránth and Morrison (2012) argue that banks that combine investment and commercial banking may be less resolvable due to "tying" of the different types of businesses. Brunnermeier, Dong, and Palia (2012) show empirically that banks with higher non-interest income contribute more to systemic risk.

${ }^{11}$ See Restrukturierungsgesetz (2010).
} 
requirements, which are now well above the new Basel III requirements. ${ }^{12}$ However, instead of implementing a pure equity buffer, the Swiss regulator decided to allow for contingent capital as part of the capital requirement. From the viewpoint of banks, contingent capital is cheaper due to the tax deductibility of interest payments. Hence, the regulation can be considered as an attempt to ensure a safe and sound banking system while maintaining banks' competitiveness.

In the following, we will derive predictions regarding these reforms' effects on banks' equity returns and CDS spreads.

\section{$2.2 \quad$ Expected Effects of Regulatory Reforms}

Table 1 gives an overview of the expected effects of the four different reform streams. In spite of the great differences in regulatory approaches, the table shows that predictions largely go in the same direction, although partly for different reasons.

Table 1: Expected Effects of Regulatory Reforms

\begin{tabular}{|c|c|l|c|c|c|c|c|c|}
\hline Reform & Country & Major elements & $\begin{array}{c}\text { Expected } \\
\text { effect on } \\
\text { equity returns }\end{array}$ & $\begin{array}{c}\text { Stronger effect on ... } \\
\text { investment } \\
\text { banks }\end{array}$ & $\begin{array}{c}\text { systemic } \\
\text { banks }\end{array}$ & $\begin{array}{c}\text { Expected } \\
\text { effect on CDS } \\
\text { spreads }\end{array}$ & $\begin{array}{c}\text { Stronger effect on ... } \\
\text { investment } \\
\text { banks }\end{array}$ & $\begin{array}{c}\text { systemic } \\
\text { banks }\end{array}$ \\
\hline $\begin{array}{c}\text { Dodd-Frank } \\
\text { Act }\end{array}$ & $\begin{array}{c}\text { United } \\
\text { States }\end{array}$ & $\begin{array}{l}\text { Prohibition of } \\
\text { activities, enhanced } \\
\text { regulation of } \\
\text { systemic } \\
\text { institutions, } \\
\text { resolution } \\
\text { procedures }\end{array}$ & $\downarrow$ & yes & yes & $\uparrow$ & yes & yes \\
\hline $\begin{array}{c}\text { Vickers } \\
\text { Report }\end{array}$ & Kningdom & $\begin{array}{l}\text { Ring-fencing } \\
\text { approach, } \\
\text { resolution } \\
\text { procedures }\end{array}$ & $\downarrow$ & yes & yes & $\uparrow$ & yes & yes \\
\hline $\begin{array}{c}\text { Restructuring } \\
\text { Law }\end{array}$ & Germany & $\begin{array}{l}\text { Resolution } \\
\text { procedures, bank } \\
\text { tax }\end{array}$ & $\downarrow$ & & yes & $\uparrow$ & & yes \\
\hline $\begin{array}{c}\text { TBTF } \\
\text { Regulation }\end{array}$ & Switzerland & $\begin{array}{l}\text { Enhanced capital } \\
\text { requirements for } \\
\text { systemic banks }\end{array}$ & $\downarrow$ & & yes & $\uparrow$ & & yes \\
\hline
\end{tabular}

All four reforms are likely to reduce the profitability of banks and hence equity prices. The Dodd-Frank Act deprives banks from profitable business (e.g., trading,

\footnotetext{
${ }^{12}$ See Expertenkommission zur Limitierung von volkswirtschaftlichen Risiken durch Großunternehmen (2010).
} 
derivatives desks), whereas the Vickers reform subjects banks to costly reorganization. German banks are subjected to a (relatively small) bank tax, whereas Swiss banks have to raise more costly equity. ${ }^{13}$ Moreover, all reforms are aimed at reducing bail-out expectations for systemic banks and are therefore expected to raise banks' CDS spreads. Rising funding costs in the presence of reduced bail-out expectations may in turn feed back into equity returns.

One notable feature of the four reforms is that they do not affect all banks to the same degree. In particular, systemic banks are expected to be affected more strongly since all reforms explicitly target systemic banks. Moreover, at least in the US and UK, investment banks are expected to be affected more strongly than commercial banks because reforms target investment banks, even if they are not considered to be systemically relevant. ${ }^{14}$

\section{Empirical Methodology}

In this section, we outline our empirical methodology. We start by describing the procedure of identifying events. Then we list data sources and present our estimation and testing procedures.

\subsection{Identification of Events}

The major challenge in any event study is the identification of "news." This is particularly true for studies of regulatory changes, for which there never is an easily identifiable single event date. We define events by investigating major newspapers of the respective countries. An incident is classified as an event if it is published as a lead article on the front page of the considered newspaper. The objective of an editor is to give larger prominence to news that people are interested in because they learn new information. For instance, the enactment of a law that has long been agreed on will not make page one. But the deal that paved the way for the

\footnotetext{
${ }^{13}$ For a discussion of whether equity is really expensive, see Admati, DeMarzo, Hellwig, and Pfleiderer (2010) and Admati and Hellwig (2013).

${ }^{14}$ In Germany and Switzerland, there exist no pure investment banks.
} 
law is more likely to make page one. This is the type of event that we want to capture. Hence, the fact that an event makes it to the front page suggests that there is something "new."

We use the Financial Times US edition for the United States, the Financial Times UK edition for the United Kingdom, Börsenzeitung and Financial Times Deutschland (FTD) for Germany, and Neue Zürcher Zeitung (NZZ) for Switzerland. ${ }^{15}$ We started our search long before the actual passage of the law in order to identify all related occurrences that may have affected reform expectations. Each regulatory event in our study consists of a sequence of events. If all relevant subevents can be identified, one can hope to capture the full effect of the reform in question even if the reform was taking place in several steps (see Lamdin, 2001). Instead of a keyword search, we investigate all front pages of the given newspaper within a broadly defined period to identify all subevents related to one of the four reform streams. This approach seems superior because headlines and articles often do not contain reform names. Moreover, we check carefully whether the announcement of the news took place before or after the markets closed on the respective day, complementing the newspaper search by an extensive internet and newspaper search. The event date typically precedes the publication date by one day except for events taking place on weekends or after market closing. Table A1 lists all subevents used in our event study, giving details about the event dates, publication dates, newspapers, and headlines. The headlines already give a good impression of the perceived effect of events. For example, the announcement of the Volcker Rule was entitled "Obama hammers the banks."

Naturally, all events have to be interpreted relative to market expectations. If a reform is weaker than had been expected initially, it may well be that the sign of the effect is reversed. This is a frequently the case when subsequent negotiations and lobby activities reverse part of the reform process, as we will see below.

\footnotetext{
${ }^{15}$ There are occasionally several editions published at one day for one newspaper. We use the default edition, retrievable on the archives of the respective newspaper.
} 


\subsection{Data}

Our analysis is based on market prices (equity and CDS) of the largest banks from the United States, United Kingdom, Germany, and Switzerland. We investigate the biggest banks from each of those countries in terms of their market capitalization. ${ }^{16}$ With regard to equity, we use daily returns of stock prices, based on closing auctions. For the credit side, we use day-to day differences in mid-prices of five-year senior credit default swap spreads (CDS spreads) on an end-of-day basis. Figures 1 and 2 depict the overall evolution of bank stock prices and CDS spreads in our sample over the years 2007 till 2011. We see a sharp rise in CDS spreads during the crisis phase, accompanied by a marked drop in stock prices. After the collapse, we observe a relaxation starting in the spring of 2009 in response to government bail-out measures and generous liquidity provision by central banks. Our period of interest covers the time from June 2009 until October 2011 following the relaxation phase when national governments started to design their own national responses to the crisis.

[Figures 1 and 2 about here]

Table 2 shows the summary statistics for our data sample. Data on bank stock prices and bank CDS spreads are taken from Datastream (Thomson Reuters). The number of observations for each bank is determined by the trading days between the first and the last observed regulatory event for each country, in addition to 140 trading days prior to the first event, required for an expanded estimation window. For this reason, the number of observations remains constant across banks within one particular country but varies across countries. For the purpose of testing for heterogeneous effects, we distinguish between investment banks and commercial banks. The distinction is based on two ratios: customer deposits as a share of total bank assets and non-interest income as a share of total bank revenue. ${ }^{17}$ Data for these ratios are from Bankscope (Bureau van Dijk). Furthermore, we split our bank

\footnotetext{
${ }^{16}$ For the United States, we used the ten largest banks, available in Datastream (Thomson Reuters). For the other countries, we use the maximum number of banks listed on the respective stock exchange.

${ }^{17}$ For this purpose, we ordered the banks in the US and UK by the first ratio in an ascending and by the second ratio in a descending manner. Summing the ranks for each bank and choosing the cut-off to be greater than 70 per cent of total possible rank score yielded the list of investment banks given in the summary statistics.
} 
sample into systemic and non-systemic banks. The selection is based on the list of 29 globally systemically important financial institutions, published by the Financial Stability Board on 4th November 2011. Table 2 also shows our classification of banks into the different categories.

[Table 2 about here]

\subsection{Estimation Procedure}

Our goal is to check for abnormal returns on every event date. We estimate normal stock returns on the basis of the market model, using a widely diversified and globally structured benchmark index, namely the Stoxx Global Total Market Index. ${ }^{18}$ The use of a broad global index avoids the contamination of effects due to the interdependency of financial and non-financial firms within a given country, and the interdependence of banks in different countries. ${ }^{19}$

The empirical model for stocks consists of a system of equations, in which bank equity returns are regressed on a constant, the return of the market index, and dummy variables that are equal to 1 at the respective event dates. The left-handside variable is the daily return of the stock of bank $j$ at time $t, j=1, \ldots J, t=1, \ldots T$. $R_{M t}$ is the return of the market portfolio (proxied by the benchmark index).

\footnotetext{
${ }^{18}$ Empirical research has shown that the market model yields very robust results, such that the use of more complicated models of stock returns seems unnecessary (see Campbell, Lo, and Mackinlay, 1996). Nevertheless, we reran our estimation for the United States according to a CAPM regression model, including the risk free rate, proxied by T-bills (see Jensen, 1968; Pettengill and Clark, 2001, for further discussion). Due to low and stable interest rates in the aftermath of the financial crisis, the results are very similar.

${ }^{19}$ See Ongena, Smith, and Michalsen (2003) for further discussion.
} 


$$
\begin{array}{ll}
R_{1 t}= & \alpha_{1}+\beta_{1} R_{M t}+\sum_{n=T-1}^{T+1} \tau_{1 n} D_{1 n t}+\epsilon_{1 t} \\
\ldots & \\
R_{j t}= & \alpha_{j}+\beta_{j} R_{M t}+\sum_{n=T-1}^{T+1} \tau_{j n} D_{j n t}+\epsilon_{j t} \\
\ldots & \alpha_{J}+\beta_{J} R_{M t}+\sum_{n=T-1}^{T+1} \tau_{J n} D_{J n t}+\epsilon_{J t}
\end{array}
$$

Note that estimation coefficients differ across assets: $\alpha_{j}$ and $\beta_{j}$ denote the bankspecific intercept and the beta factor attached to the market return, respectively. $D_{j n t}$ indicates a vector of dummy variables for all subevents. For each subevent, there are three dummies: a pre-event dummy, which is equal to 1 one day before the event, $T-1$, (and zero otherwise) to capture anticipatory effects; an event dummy that takes the value one on the day of the event, $T$ (and zero otherwise); and finally a post-event dummy, which is equal to 1 one day after the event, $T+1$ (and zero otherwise). When the estimation period includes other dates identified as event dates, such events are "dummied out" by including the respective event dummies in the regression; the estimation window is widened accordingly. This guarantees that normal returns are not mismeasured due to other regulatory events in the estimation period. In order to check the robustness of our results, we use two different estimation windows. The estimation window begins either 80 or 140 trading days before the event and ends one day prior to the event date. The estimated coefficient $\tau_{j n}$ on the dummies delivers the abnormal return for each individual bank stock for a given day in the event window. These coefficients are tested separately and in different aggregated manners for significance.

We estimate this system of regressions in a SUR framework (seemingly unrelated regressions, Zellner, 1962) instead of employing the traditional two-stage procedure for each individual asset, as described by Campbell, Lo, and Mackinlay (1996). This is the preferred method of dealing with "clustered" events, which affect many firms 
at the same time. ${ }^{20}$

We model the normal returns of banks' CDS spreads on the basis of the constant return model. The only difference, compared to the market model above, consists in the fact that no market return is used for the estimation of normal returns (see Campbell, Lo, and Mackinlay, 1996):

$$
\begin{array}{r}
\Delta C D S_{1 t}=\mu_{1}+\sum_{n=T-1}^{T+1} \tau_{1 n} D_{1 n t}+\epsilon_{1 t} \\
\ldots \\
\Delta C D S_{j t}=\mu_{j}+\sum_{n=T-1}^{T+1} \tau_{j n} D_{j n t}+\epsilon_{j t} \\
\ldots \\
\Delta C D S_{J t}=\mu_{J}+\sum_{n=T-1}^{T+1} \tau_{J n} D_{J n t}+\epsilon_{J t},
\end{array}
$$

where $\triangle C D S_{j t}$ is the first difference of CDS spreads, and $\mu_{j}$ denotes the mean of first differences of bank $j$ within the estimation window. Otherwise, the estimation procedure is the same as for stock returns.

\subsection{Testing}

The estimated abnormal returns can be used to carry out a number of different tests. In the regression tables below, we present significance tests for the average abnormal return across banks on the event day $T$. In a SUR framework, it is straightforward to run such tests, taking into account contemporaneous correlations across stocks. In order to analyze the heterogeneity of effects, we also run separate tests for different types of banks. In the regression tables, we only display the differences between different bank groups (investment banks vs. commercial banks, systemic vs. non-systemic banks) and the respective significance tests. We also test

\footnotetext{
${ }^{20}$ See Binder (1985) and Karafiath (1988).
} 
for anticipation effects by considering average abnormal returns on day $T-1$. The results are reported only if they are significant. In addition, we ran significance tests for the average cumulated return across banks over days $T$ and $T+1$. The results of these tests are displayed only if the abnormal return on date $T+1$ turned out to be significant.

Event studies of regulatory reforms may suffer from low power. For example, an imprecise timing of events reduces the power of significance tests, i.e. raises the type II error, implying that one may not be able to reject the null hypothesis of no effect when the true effect is nonzero. In our estimation, we raise the power of significance tests by using daily return data, using short event windows (one or two days), and varying the length of the estimation window. These factors have been shown to increase the power of significance tests in event studies (see MacKinlay, 1997). Long event windows lead to a downward bias because they may contain many days without any news. Moreover, the shorter the event window, the less likely is the occurrence of other confounding events. In addition, we check directly whether other events not related to the considered reform took place at the same time. This becomes an issue at the time of the Greek debt crisis. Averaging may reduce the power of tests because positive and negative effects may compensate each other. This would, for example, be the case if a reform benefits some banks and harms others, which could on average lead to a zero effect. This problem is mitigated if abnormal returns are measured separately for different bank groups, as is done in our tests for heterogenous effects.

\section{Results}

We now present our empirical results, starting with the United States, where the first reforms were initiated, then continuing with the United Kingdom, Germany, and Switzerland. Our main results are listed in Tables 3 to 7 . They show the abnormal returns in equity prices and CDS spreads for all subevents, for which any significant reaction could be found either in equity prices or CDS spreads. The full list of results for all identified subevents can be found in the Appendix (see 
Tables A2 to A5). ${ }^{21}$

\subsection{United States - The Dodd-Frank Act}

Table 3 presents the regression results for the Dodd-Frank Act in the United States (see Table A2 for detailed results on all subevents). The left panel shows the results on equity returns, the right panel those on CDS spreads. For each subevent, the table first displays the average overall return and then average abnormal returns for estimation windows of 80 and 140 days. The final two columns display differential abnormal returns of investment vs. commercial banks and systemic vs. non-systemic banks, respectively. The results for the enlarged event window are shown only if the post-event day showed a significant abnormal return. The last line of the table presents the sum of returns over all subevents. When the enlarged event window is shown, the summation considers the total effect including day $T+1$ even if the effect of that day was insignificant. This avoids a summation of different event days for different columns (but it may bias the results against finding an overall effect).

[Table 3 about here]

Looking first at the summation line, the overall effect of the Dodd-Frank Act was a sharp increase in CDS spreads and a drop in equity prices. Hence, the reform lowered the profitability of banks by prohibiting profitable banking activities, but at the same time lowered bail-out expectations by enhancing prudential regulation and improving resolution procedures. The results are also quantitatively important. The sum of abnormal equity returns is around three percentage points, and CDS spreads increase by more than 35 basis points. Compared to the reforms in the other countries, especially the effect on CDS spreads is very large. The drop in equity prices was more pronounced for investment banks and systemic banks (relative to commercial and non-systemic banks, respectively). The same result is found for CDS spreads, although the differential between investment and commercial banks is relatively small. Hence, the heterogeneity of effects overall points in the expected

\footnotetext{
${ }^{21}$ The results on anticipation effects are reported in the Appendix tables if they turn out to be significant. In most cases, there are no significant market reactions. In a few instances, we do find anticipatory effects, which will be discussed below.
} 
direction. However, markets do not seem to have anticipated a markedly different decrease in bail-out expectations for investment banks relative to commercial banks. Considering individual subevents, we find that a large part of the overall effect is driven by the market reactions to the announcement of the Volcker Rule. For that subevent alone, CDS spreads rose by around 17 basis points. The effect on equity prices is also quite large, although - somewhat surprisingly - insignificant. ${ }^{22}$ The differential reactions of different bank groups are also pronounced during this subevent. The evolution of stock returns and CDS spreads around this date is depicted in Figures 3 to 6 . The figures show the general drop in equity prices and increase in CDS spreads. We can also see a discrete widening of the differential between investment and commercial banks, and systemic and non-systemic banks after the announcement. However, especially for stocks, there also seems to have been a more gradual widening of the differential already before the announcement.

[Figures 3 - 6 about here]

The second noteworthy subevent is the dilution of the reform when the reform bill was finally agreed upon by democrats and republicans. The reform proposal was diluted to the extent that proprietary trading as well as hedge fund and private equity investments were now allowed to be conducted up to 3 per cent of a bank's capital. Moreover, the rule regarding the spin-off of lucrative derivatives desks was weakened. The "bouncing back" in stock returns indirectly supports the view that the initial reform was effective, although the total effect of the actual reform is reduced. Nevertheless, the total effect of the reform still points in the intended direction. The dilution is hardly visible in CDS spreads as the rules affecting bailout expectations were not watered down in the final negotiations. Overall, the results point clearly towards a decrease in both bail-out expectations and banks' profitability.

\footnotetext{
${ }^{22} \mathrm{~A}$ possible explanation is that the slide in bank stock prices provoked a downturn in the overall stock market when the Volcker Rule was announced. There even was a positive anticipation effect for equity (see Table A2), which, however, seems to have been related to a decrease in credit losses reported by several large US banks.
} 


\subsection{International Spillover Effects of the Dodd-Frank Act}

The Dodd-Frank Act was the first major structural reform in response to the global financial crisis. Such a major reform is likely to have had effects beyond national borders. Therefore, we test for spillover effects from the reform to the banks in the United Kingdom, Germany, and Switzerland. It is conceivable that the reform in the United States sent a signal to the world that tougher regulation would also come about elsewhere.

In order to test for spillover effects, we checked whether any of the events regarding the Dodd-Frank Act led to a frontpage article in the other three countries. We identified three subevents that also appeared on the front pages in the other countries. For these three events, we estimate abnormal returns for UK, German, and Swiss banks. The results are found in Table 4.

[Table 4 about here]

We find substantially negative abnormal returns in the equity market for the United Kingdom and Switzerland. ${ }^{23}$ In contrast, no significant spillovers to Germany can be found. As the British banking industry is similar to and strongly connected with the US banking industry, a spillover effect would have been expected. The average effect in Switzerland is smaller, which may however be driven by the fact that the two largest banks were hit strongly, whereas the cantonal banks, which are not very active in the trading and derivatives business, were hardly affected. This also explains why we find a highly significant coefficient for the difference between systemic and non-systemic banks in Switzerland.

Since market reactions to the Dodd-Frank Act anticipate future national reform efforts in the other three countries, we also include the spillover events in the tables for these countries. These will be discussed next.

\subsection{United Kingdom - The Vickers Reform Proposals}

We now consider the second big reform stream, which is the Vickers reform in the United Kingdom, with the ring-fencing approach in its center. The results are

\footnotetext{
${ }^{23}$ We also find a positive anticipation effect in CDS markets for the UK (see Table A3).
} 
displayed in Table 5 (detailed results for all subevents are found in Table A3). As shown by the summation line, we find a marked overall increase in CDS spreads of more than 15 basis points in response to the reform, whereas the effect on stock markets is modest. In the CDS market, we again find stronger effects for investment banks (by 6 basis points) and especially for systemic banks (by 18 basis points). Hence, the reform seems to have credibly reduced bail-out expectations for systemic banks in the UK.

\section{[Table 5 about here]}

The relatively small effect on equity markets is explained by the strong positive effect of the announcement to postpone the Vickers reform to the post-election period beyond 2015. This shifted bank reorganization and other costly consequences of the ring-fencing approach to the far and uncertain future and led to a rebound in equity prices by almost 9 percentage points, when considering the enlarged event window of 2 days cumulated stock returns. The postponement also shows up in CDS spreads, but here the overall effect remains strongly positive. The final publication of the Vickers Report had a large positive effect on CDS spreads, especially for systemic banks. ${ }^{24}$ The differential effect for investment banks is much smaller, which can be explained by the uncertainty surrounding the time of implementation of the ringfencing approach. This is also in line with the particularly sharp decrease in this differential after the announcement of the postponement.

Figures 7 to 10 illustrate the reactions of equity prices and CDS spreads for both groups of banks around the postponement and the final publication of the Vickers Report. Equity prices do not show a clear upward movement, but are largely flat, consistent with the regression results (see Figures 7 and 8). In contrast, CDS spreads clearly move upwards, although the movement is more gradual than it was, for example, around the announcement of the Volcker rule (see Figures 9 and 10). We can also see the negative differential between systemic and non-systemic banks after the postponement, which is reduced again at the publication date (see Figure 10). The overall big differential effect is not visible in the graph, which only shows a small subset of events out of the entire reform process.

\footnotetext{
${ }^{24}$ There were also some anticipation effects both for the postponement and for the publication, further strengthening the observed effects on the event days (see Table A3).
} 
[Figure 7 - 10 about here]

Just as for the Dodd-Frank Act, the overall effect of the Vickers reform proposal seems to have been a reduction in bail-out expectations, especially for systemically relevant financial institutions. The effect on profitability is, however, smaller than that observed in the United States.

\subsection{Germany - The Restructuring Law and Bank Tax}

In contrast to the United States and the United Kingdom, the German reform package focuses on the bank resolution process instead of implementing elements of a separate banking system. We now investigate market reactions in response to the introduction of the German restructuring law and bank tax.

[Table 6 about here]

The results are shown in Table 6 . We find that just a single subevent produces significant market reactions (see Table A4 for detailed results on all subevents). The overall effect on stock returns and CDS spreads is small and insignificant. However, we do find a stronger increase in CDS spreads for systemic relative to non-systemic banks after the agreement on the key points of the bill, as would be expected for a reform that intends to reduce too-big-to-fail expectations. However, the effect is small (around 5 basis points) compared to those observed in the other reforms. Given the limited effectiveness of the reform due to the unresolved issue of cross-border banks and the small tax rate, this is not surprising.

Figure 11 depicts the evolution of CDS spreads around the announcement and shows nicely how CDS spreads of systemic and non-systemic banks discretely shift apart at the event date. Hence, the reform has exactly the intended effect to reduce bail-out expectations, but is not ambitious enough to produce large effects.

[Figure 11 about here]

\subsection{Switzerland - The Too-Big-to-Fail-Regulation}

Finally, we turn to the Swiss too-big-to-fail regulation, which stipulates enhanced equity buffers for systemic banks. The results are given in Table 7 (see Table A5 for 
the results on the full set of subevents). As shown in the summation line, we observe an overall decrease in equity prices and a surge in CDS spreads. Interestingly, the drop in equity prices is mainly driven by the spill-over effect of the Volcker Rule as described above. The too-big-to-fail regulation itself does not produce additional stock price effects, indicating that higher equity buffers were not perceived to impose costs on banks over and above those that had already been priced in before. In contrast, the too-big-to-fail regulation produces strong and significant effects on CDS spreads, which rise by almost 10 basis points after the presentation of the preliminary report by the Too-Big-to-Fail Commission. Results on both equity prices and CDS spreads would be even bigger when taking into account anticipation effects (see Table A5). The increase in CDS spreads is also visible in Figure 12. The figure also shows that the increase started already one day before the event, illustrating the anticipation effects. Since CDS data only exist for systemic banks in Switzerland, a distinction between systemic and non-systemic banks is not feasible here.

[Table 7 about here]

[Figure 12 about here]

Overall, the results suggest that the reform was able to lower bail-out expectations. The relatively modest effect of the too-big-to-fail regulation on stock prices can be attributed to the allowance of contingent capital in increased equity buffers. Summing up, all four reform streams appear to affect bail-out expectations in the intended direction. The effects on stock prices, however, appear to depend on the design of the regulation.

\section{Conclusion}

In this paper we asked the question: Has anything happened in financial regulation after the crisis? Have the various structural reforms enacted in countries hosting major financial centers been registered in equity valuations and credit default spreads of their banks? The good news is that the answer is yes. In all cases, the reforms seem to have reduced bail-out expectations, especially for systemic banks, and lowered equity returns in many cases. We find the strongest results for the Dodd-Frank 
Act and, in particular, the Volcker rule, which led to a significant decrease in equity prices and an increase in CDS spreads, especially for investment banks and systemic banks. The announcement of the Volcker rule also produced significant spillover effects to banks in the United Kingdom and to Switzerland. The response of market prices to the Vickers reform was a marked increase in CDS spreads, but less so in equity prices. In both instances, there were reversals when the reforms were watered down or postponed. In Germany, the introduction of a special resolution regime for systemic banks led to an increase in CDS spreads of such banks. Finally, in Switzerland, the too-big-to-fail regulation, which requires systemic banks to hold significantly higher levels of capital, led to a strong increase in CDS spreads of systemic banks.

These results give rise to obvious follow-up questions, such as: Has enough happened? The bad news is that we cannot really tell. There are several reasons why this is a much harder question to answer. The most important one is that we are ultimately interested in the safety of the financial system. While evidence suggests that lower bail-out expectations lead to lower risk-taking ${ }^{25}$, our methodology is silent on this issue. In fact, with the data currently available, this question cannot be answered reliably. Only the future will tell. Moreover, it is not quite clear what is "enough." For sure, the goal of reforms cannot be to generate the largest possible drop in equity prices and increase in CDS (By that measure, a reform that shuts down the system would be considered as a successful reform). Rather the measure of a successful reform should be that it eliminates the distortions stemming from systemic risk. One possible approach is to compare our results quantitatively with the funding cost differentials created by government support. According to Ueda and Weder di Mauro (2013), the value of the subsidy as of 2009 was as much as 60 to 80 basis points funding cost differential. Measured against this benchmark, we would conclude that none of the national reforms has been enough to fully eliminate the distortion.

The next question is whether some forms of structural reforms are better than others. After all there are different underlying and competing philosophies behind the

\footnotetext{
${ }^{25}$ See, for example, Boyd and Gertler (1994), Schnabel (2009), and Gropp, Hakenes, and Schnabel (2011) on the effect of too-big-to-fail guarantees on banks' risk-taking.
} 
various reforms. The US and UK reform, in particular the Volcker Rule and the ringfencing approach by Vickers, have the experience with separate banking systems as intellectual backdrops. By contrast, the Swiss and German reforms aim at increasing capital buffers and improving resolvability. It would be tempting to conclude by looking at the size of CDS spread changes that the US-type structural reform is the most effective. However, this would not necessarily be the right conclusion. Without doubt, the Volcker rule came as a bombshell. But apart from signaling the type of future reforms, this announcement made clear that national governments unilaterally would go beyond the fine-tuning of Basel regulations, which surprised investors all over the world. On the other side of the spectrum, it would be incorrect to conclude from the comparatively small effect that the German reform had on CDS spreads that resolutions regimes are generally ineffective. The problem of the German restructuring regime is not that it is ineffective in principle but that it turns out to be irrelevant in practice since it is implemented at the national level.

National restructuring regimes cannot solve the cross-border coordination issues, which proved to be crucial in the financial crisis. In the Euro area, this problem has been recognized and a supranational resolution regime is planned as part of the future banking union. But at the global level, the chances of solving the crossborder coordination issues are slim. The Basel process has delivered a framework of capital regulation but there is no robust framework for cross-border resolution. Unfortunately, the fact that different large countries are following different strategies in reforming their banking systems may actually make this cross-border coordination problem larger rather than smaller. This would be really bad news. 


\section{References}

Admati, A., and M. Hellwig (2013): The Bankers' New Clothes. Princeton and Oxford: Princeton University Press.

Admati, A. R., P. M. Demarzo, M. F. Hellwig, and P. C. Pfleiderer (2010): "Fallacies, Irrelevant Facts, and Myths in the Discussion of Capital Regulation: Why Bank Equity is not Expensive," Max Planck Institute for Research on Collective Goods, Bonn, Preprint No. 2010/42.

Baele, L., O. De Jonghe, and R. Vander Vennet (2007): "Does the Stock Market Value Bank Diversification?," Journal of Banking and Finance, 31, 19992023.

BINDER, J. J. (1985): "Measuring the effects of regulation with stock price data," The RAND Journal of Economics, 16(2), 167-183.

Bongini, P., M. L. Di Battista, L. Nieri, and M. Pelagatti (2012): "The value of being systemically important financial institutions," Working Paper.

Boyd, J. H., And M. Gertler (1994): "The Role of Large Banks in the Recent U.S. Banking Crisis," Federal Reserve Bank of Minneapolis Quarterly Review, $18(1), 2-21$.

Brunnermeier, M. K., G. Dong, And D. Palia (2012): "Banks' NonInterest Income and Systemic Risk," SSRN Working Paper, available at: http://ssrn.com/abstract $=1786738$.

Campbell, J. Y., A. W. Lo, and A. C. Mackinlay (1996): The Econometrics of Financial Markets. Princeton: Princeton University Press.

Chow, J. T., And J. Surti (2011): "Making Banks Safer: Can Volcker and Vickers Do It?," International Monetary Fund Working Paper No. 11-236, Washington, D.C.

De Jonghe, O. (2010): "Back to the Basics in Banking? A Micro-Analysis of Banking System Stability," Journal of Financial Intermediation, 19, 387-417. 
DemirgüÇ-Kunt, A., And H. Huizinga (2010): "Bank Activity and Funding Strategies: The Impact on Risk and Returns," Journal of Financial Economics, $98,626-650$.

DodD-Frank Act (2010): "The Dodd-Frank Wall Street Reform and Consumer Protection Act," H.R. Bill No.4173, (July 21), 111th Congress of the United States, House of Representatives.

EXPERTENKOMMISSION ZUR LIMITIERUNG VON VOLKSWIRTSCHAFTLICHEN Risiken Durch Grossunternehmen (2010): "Schlussbericht der Expertenkommission zur Limitierung von volkswirtschaftlichen Risiken durch Großunternehmen," Bern.

Eyssell, T., And N. Arshadi (1990): "The Wealth Effects of the Risk-based Capital Requirement in Banking: The Evidence from the Capital Markets," Journal of Banking and Finance, 14(1), 179-197.

Financial Stability Board (2009): "Improving Financial Regulation," Report of the Financial Stability Board to G20 Leaders, Basel.

Fratianni, M. U., and F. Marchionne (2009): "Rescuing Banks from the Effects of the Financial Crisis," MoFir Working Paper Series, No. 30.

Gropp, R., H. Hakenes, and I. Schnabel (2011): "Competition, Risk-Shifting, and Public Bail-out Guarantees," Review of Financial Studies, 24(6), 2084-2120.

High-Level Expert Group (2012): "Reforming the Structure of the EU Banking Sector," Final Report, Brussels.

Jensen, M. (1968): "The Performance of Mutual Funds in the Period 1945-1964," Journal of Finance, 23(2), 389-416.

Karafiath, I. (1988): "Using Dummy Variables in the Event Methodology," The Financial Review, 23(3), 351-357.

LAMDin, D. J. (2001): "Implementing and interpreting event studies of regulatory changes," The Financial Review, 53(2-3), 171-183. 
Lepetit, L., E. Nys, P. Rous, and A. Tarazi (2008): "Bank Income Structure and Risk: An Empirical Analysis of European Banks," Journal of Banking and Finance, 32, 1452-1467.

Lóránth, G., And A. D. Morrison (2012): "Tying in Universal Banks," Review of Finance, 16, 481-516.

MacKinlay, A. C. (1997): "Event Studies in Economics and Finance," Journal of Economic Literature, 35(1), 13-39.

O'Hara, M., And W. ShaW (1990): "Deposit Insurance and Wealth Effects: The Value of Being 'Too Big To Fail'," Journal of Finance, 45(5), 1587-1600.

Ongena, S., D. C. Smith, and D. Michalsen (2003): "Firms and their distressed banks: lessons from the Norwegian banking crisis," Journal of Financial Economics, 67, 81-112.

Pettengill, G. N., and J. M. Clark (2001): "Estimating Expected Returns in an Event Study Framework: Evidence from the Dartboard Column," Quarterly Journal of Business and Economics, 40(3/4), 3-21.

RestrukturierungSGesetz (2010): "Gesetz zur Restrukturierung und geordneten Abwicklung von Kreditinstituten, zur Errichtung eines Restrukturierungsfonds für Kreditinstitute und zur Verlängerung der Verjährungsfrist der aktienrechtlichen Organhaftung (Restrukturierungsgesetz)," Bundesgesetzblatt Jahrgang 2010 Teil I Nr. 63, Bonn am 14. Dezember 2010.

SChnABEL, I. (2009): "The Role of Liquidity and Implicit Guarantees in the German Twin Crisis of 1931," Journal of International Money and Finance, 28(1), $1-25$.

Schwert, G. W. (1981): "Measuring the Effects of Regulation: Evidence from the Capital Markets," Journal of Law and Economics, 24, 121-145.

Spiegel, M. M., And N. Yamori (2003): "The impact of Japan's financial stabilization laws on bank equity values," Journal of the Japanese and International Economies, 17(3), 263-282. 
Stiroh, K. J. (2006): "Diversification in Banking: Is Noninterest Income the Answer?," Journal of Money, Credit and Banking, 36(5), 853-882.

Ueda, K., And B. Weder di Mauro (2010): "The Value of the Too-Big-toFail Subsidy to Financial Institutions," in Financial Sector Taxation: The IMF's Report to the G-20 and Background, pp. 106-116. Stijn Claessens, Michael Keen, Ceyla Pazarbasioglu (eds.), International Monetary Fund, Washington.

(2013): "Quantifying Structural Subsidy Values for Systemically Important Financial Institutions," International Monetary Fund Working Paper No. 12/128, Washington, D.C., forthcoming in Journal of Banking and Finance.

United Kingdom Independent Commission on Banking (2011): "Final Report Recommendations," London.

Veronesi, P., And L. Zingales (2010): "Paulson's Gift," Journal of Financial Economies, 97(3), 339-368.

Zellner, A. (1962): "An Efficient Method of Estimating Seemingly Unrelated Regressions and Tests for Aggregation Bias," Journal of the American Statistical Association, 57, 348-368. 
Figure 1. Bank Stock Prices

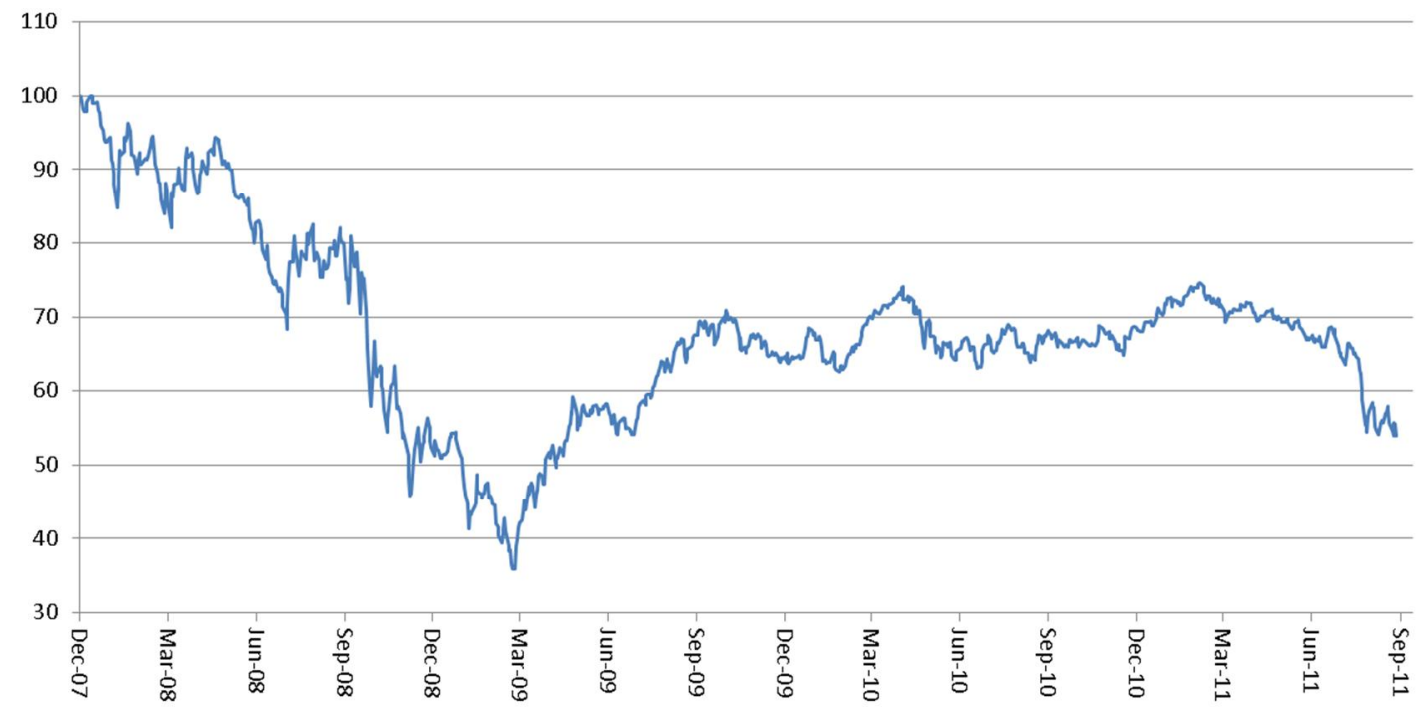

The figure shows the reaction of global stock prices of all banks in our sample. The graph shows an equally weighted index for stock prices, ranging from D ecember 2007 to October 2011.

Figure 2. CDS Spreads

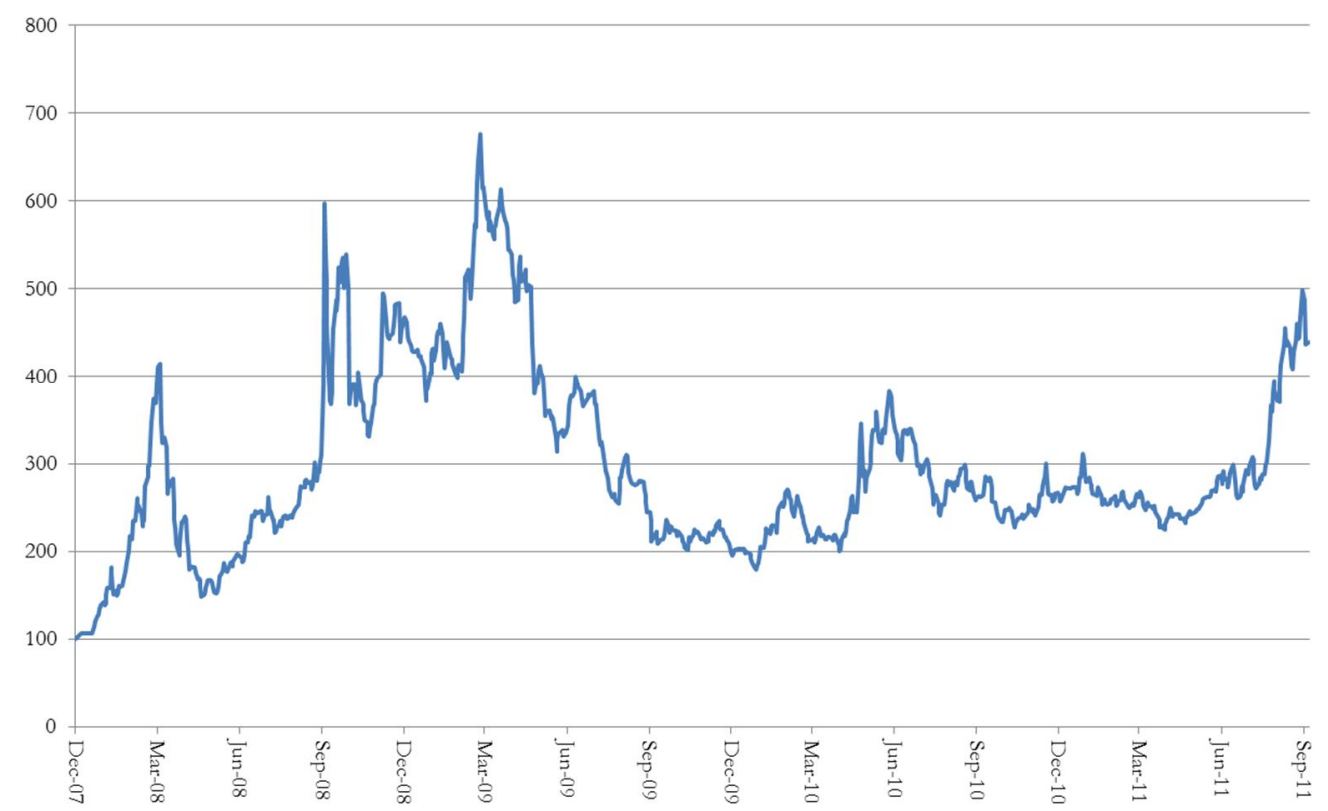

The figure shows the reaction of CD S spreads of all banks in our sample. The graph shows an equally weighted index for CD S spreads, ranging from December 2007 to O ctober 2011. 
Figure 3. The Volcker Rule | U.S. Stocks of Investment and Commercial Banks

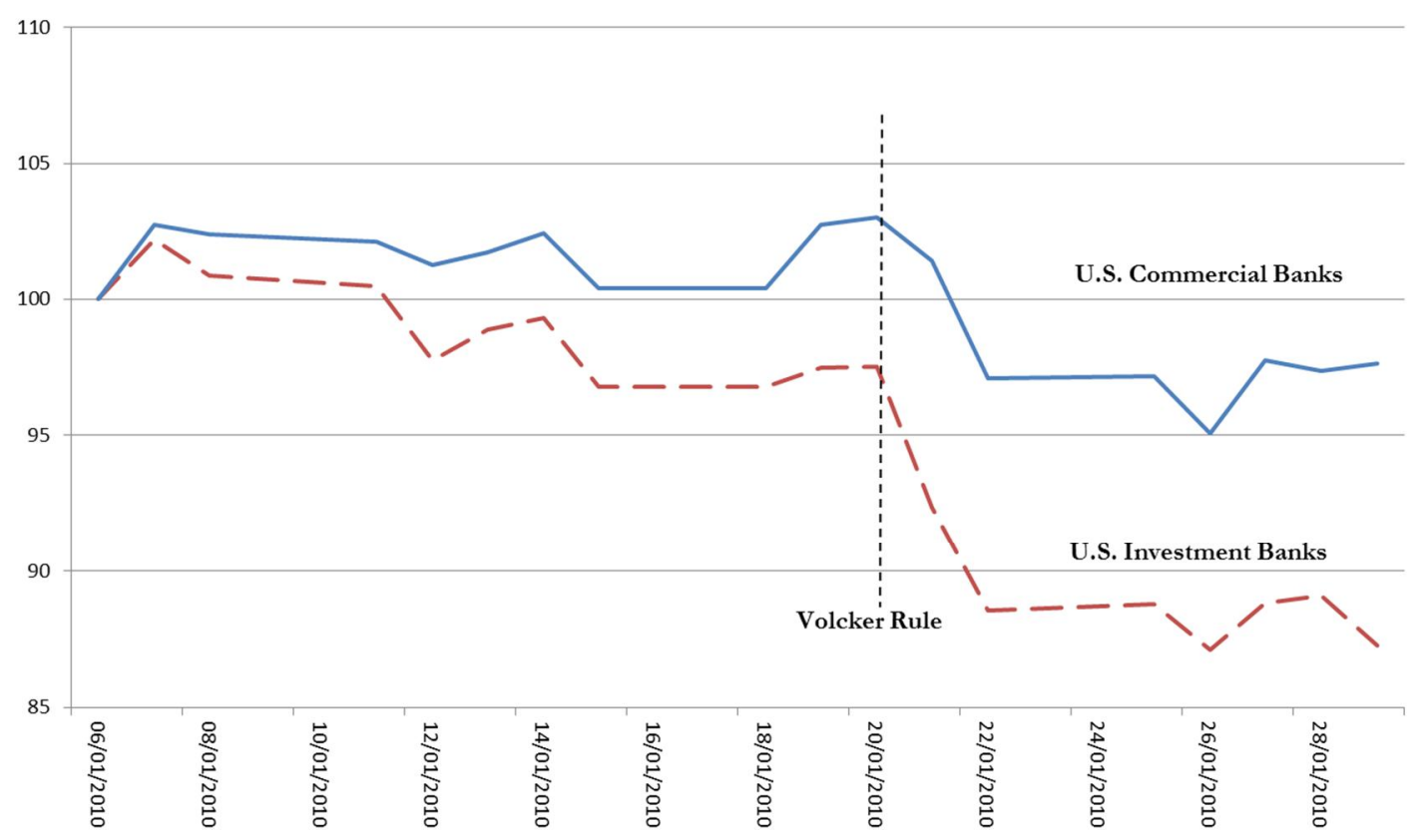

The figure shows the reaction of stock prices to the indicated regulatory event in the US. The graphs show equally weighted indices for stock prices, starting approximately two weeks prior to the announcement of the event. The two graphs refer to investment and commercial banks.

Figure 4. The Volcker Rule | U.S. Stocks of Systemic and Non-Systemic Banks

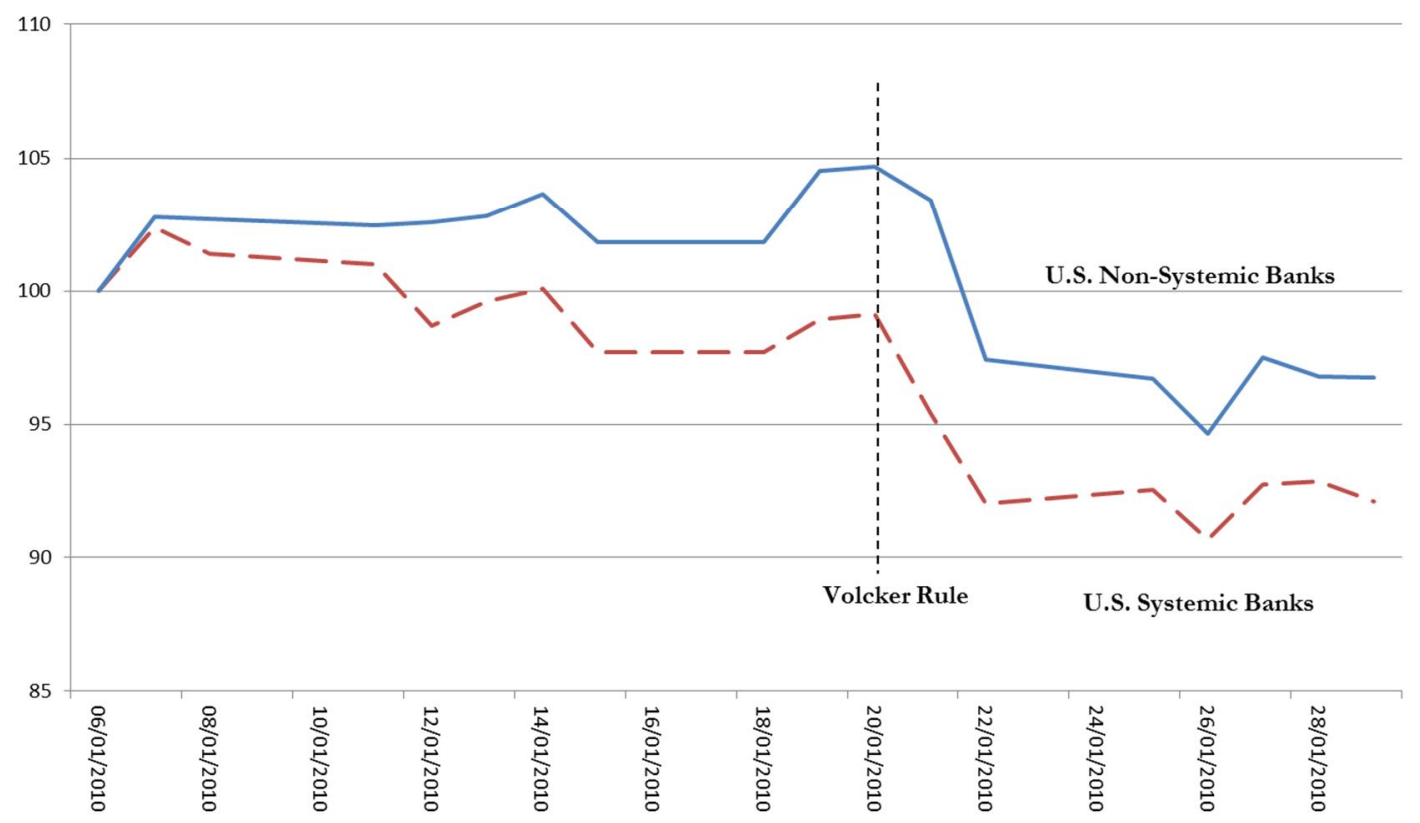

The figure shows the reaction of stock prices to the indicated regulatory event in the US. The graphs show equally weighted indices for stock prices, starting approximately two weeks prior to the announcement of the event. The two graphs refer to systemic and non-systemic banks. 
Figure 5. The Volcker Rule | U.S. CDS Spreads of Investment and Commercial Banks

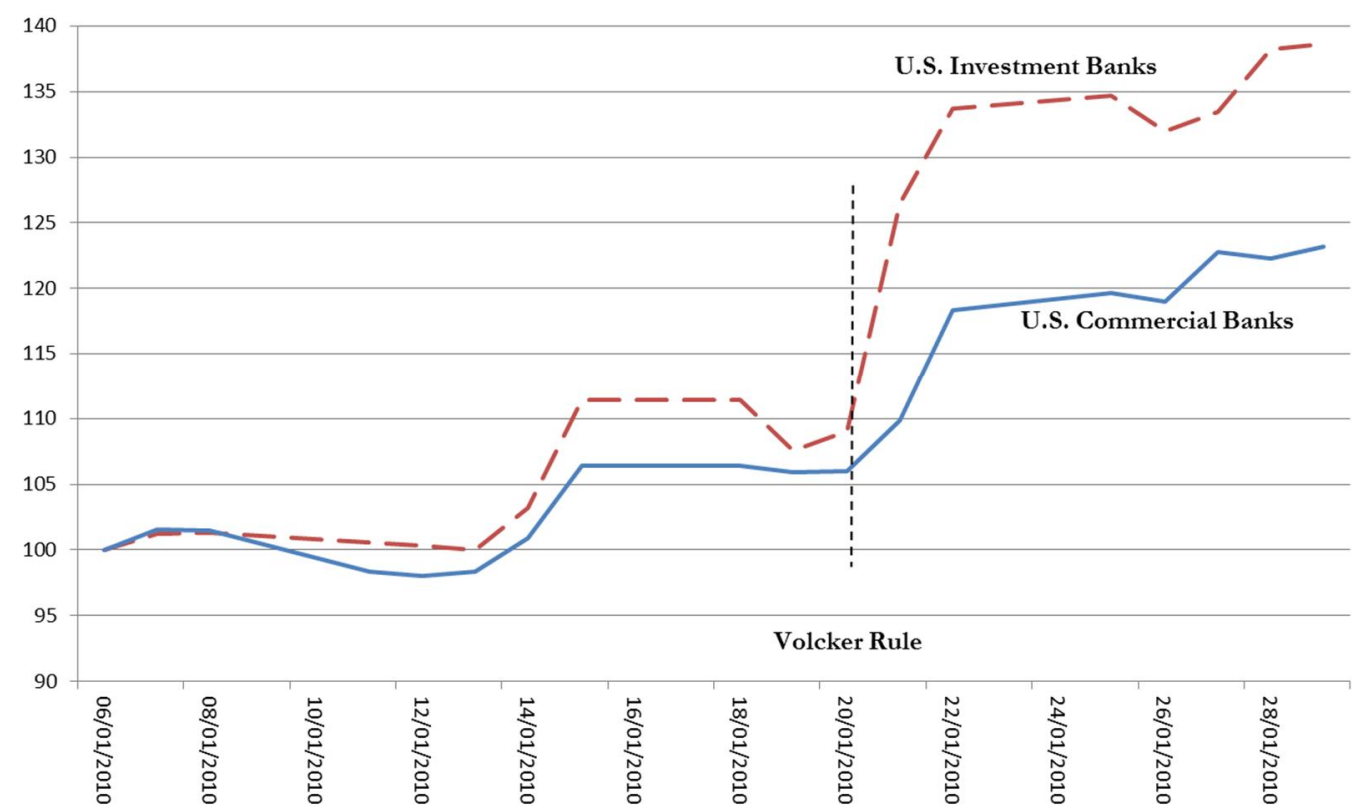

The figure shows the reaction of CDS spreads to the indicated regulatory event in the US. The graphs show equally weighted indices for CDS spreads, starting approximately two weeks prior to the announcement of the event. The two graphs refer to investment and commercial banks.

Figure 6. The Volcker Rule | U.S. CDS Spreads of Systemic and Non-Systemic Banks

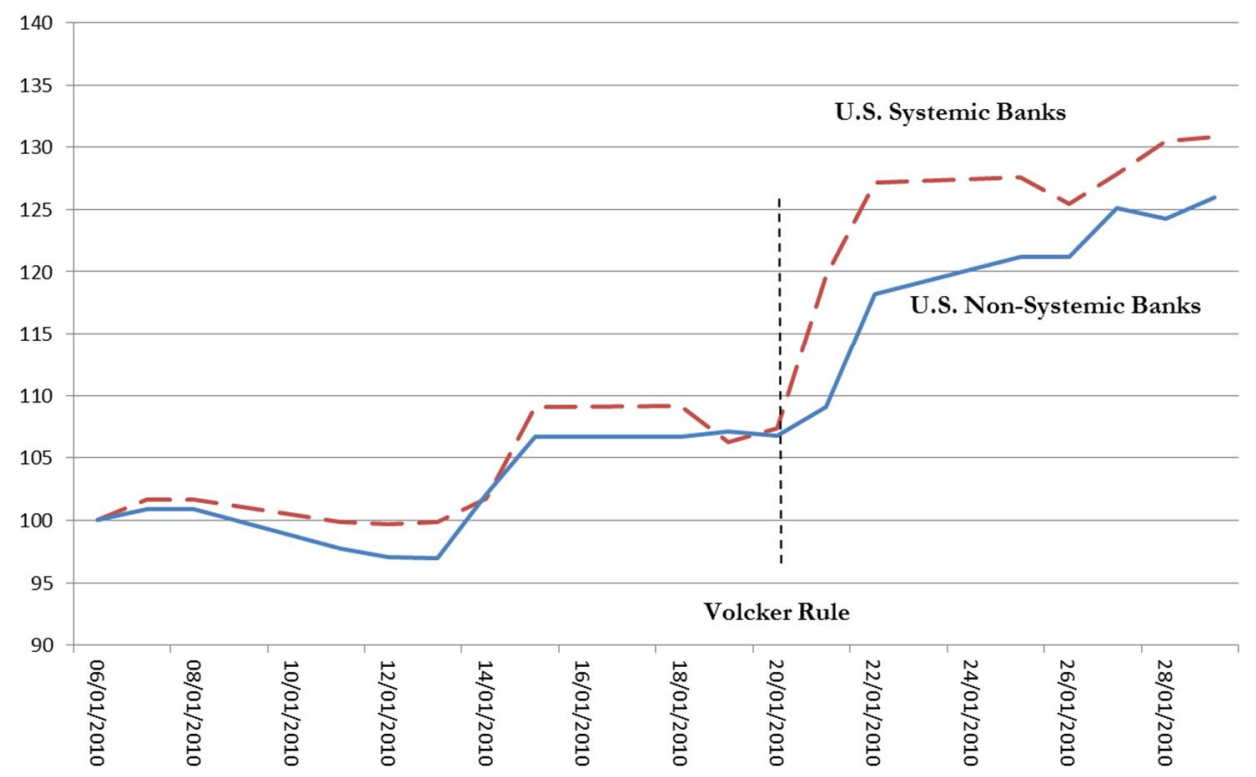

The figure shows the reaction of CDS spreads to the indicated regulatory event in the US. The graphs show equally weighted indices for CDS spreads, starting approximately two weeks prior to the announcement of the event. The two graphs refer to systemic and non-systemic banks. 
Figure 7. The Vickers Reform | U.K. Stocks of Investment and Commercial Banks

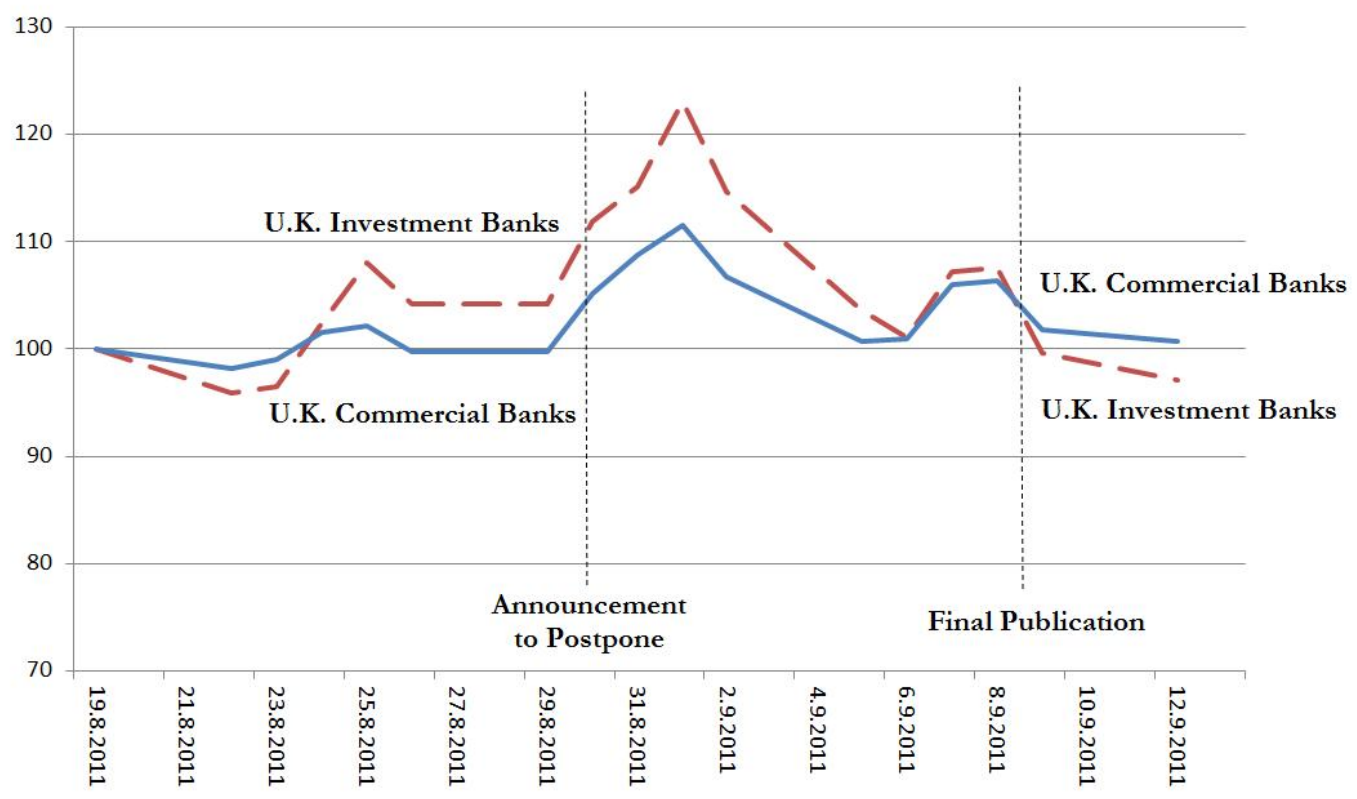

The figure shows the reaction of stock prices to the indicated regulatory events in the UK. The graphs show equally weighted indices for stock prices, starting approximately two weeks prior to the announcement of the first event. The two graphs refer to investment and commercial banks.

Figure 8. The Vickers Reform | U.K. Stocks of Systemic and Non-Systemic Banks

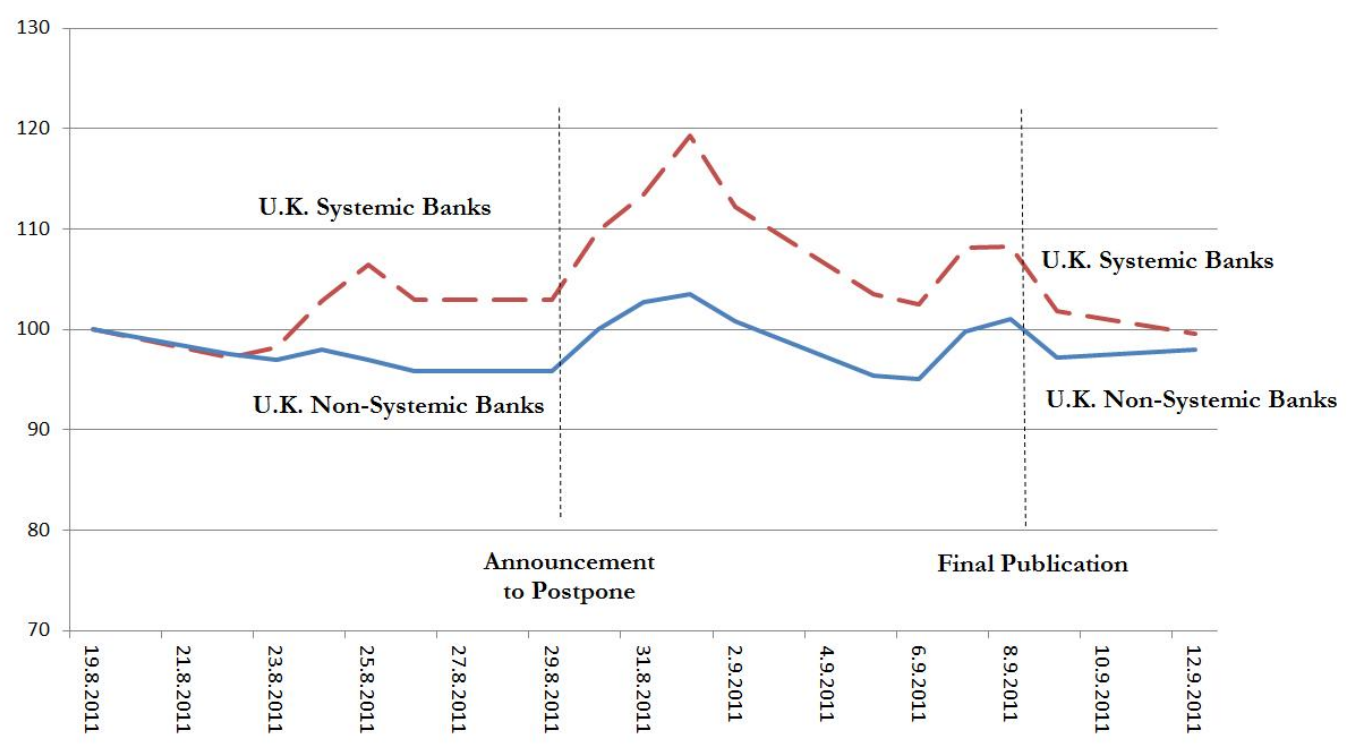

The figure shows the reaction of stock prices to the indicated regulatory events in the UK. The graphs show equally weighted indices for stock prices, starting approximately two weeks prior to the announcement of the first event. The two graphs refer to systemic and non-systemic banks. 
Figure 9. The Vickers Reform | U.K. CDS Spreads of Investment and Commercial Banks

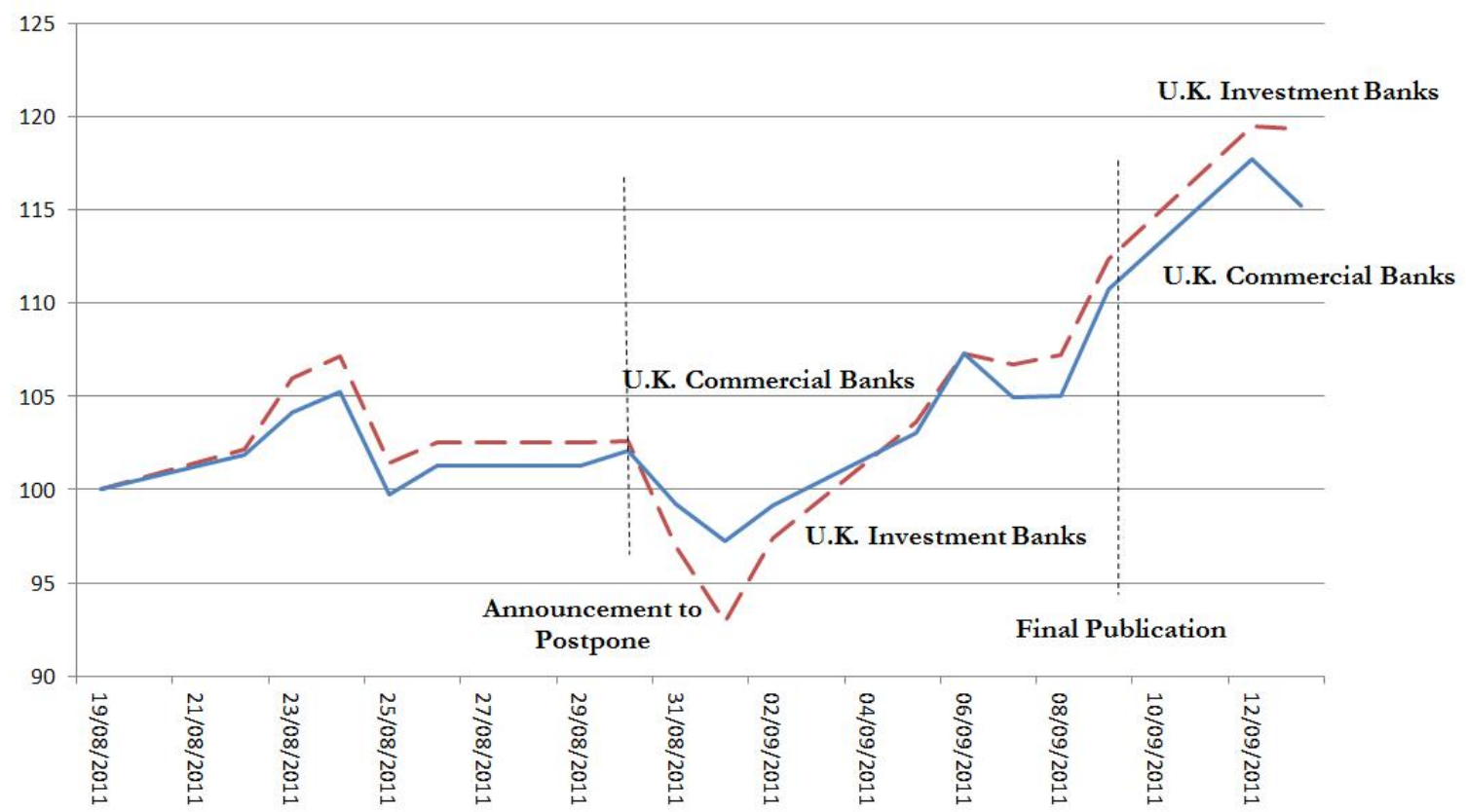

The figure shows the reaction of CDS spreads to the indicated regulatory events in the UK. The graphs show equally weighted indices for CD S spreads, starting approximately two weeks prior to the announcement of the first event. The two graphs refer to investment and commencial banks.

Figure 10. The Vickers Reform | U.K. CDS Spreads of Systemic and Non-Systemic Banks

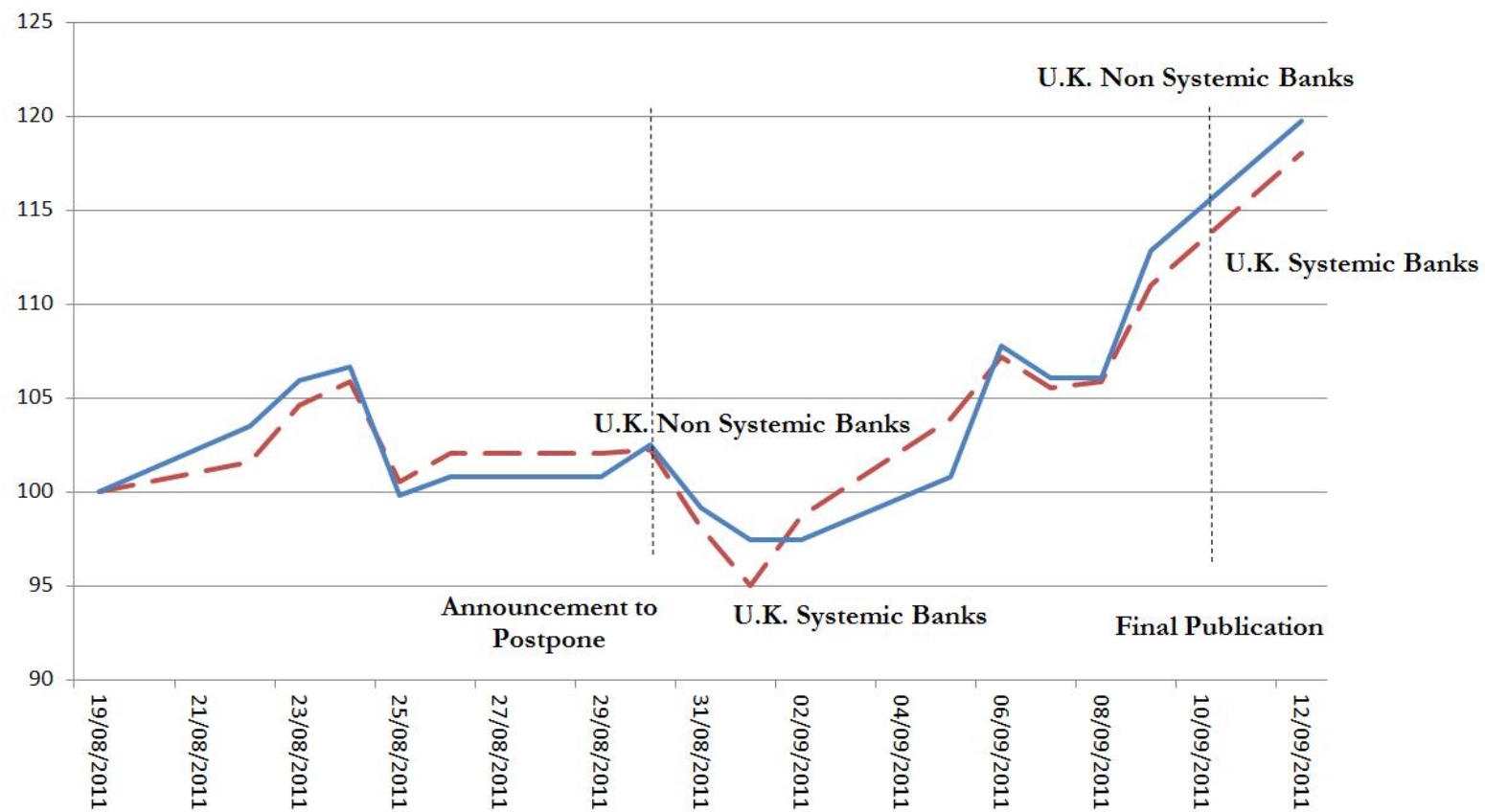

The figure shows the reaction of CDS spreads to the indicated regulatory events in the UK. The graphs show equally weighted indices for CD S spreads, starting approximately two weeks prior to the announcement of the first event. The two graphs refer to systemic and non-systemic banks. 
Figure 11. German Bank Tax and Restructuring Law | German CDS Spreads of Systemic and Non-Systemic Banks

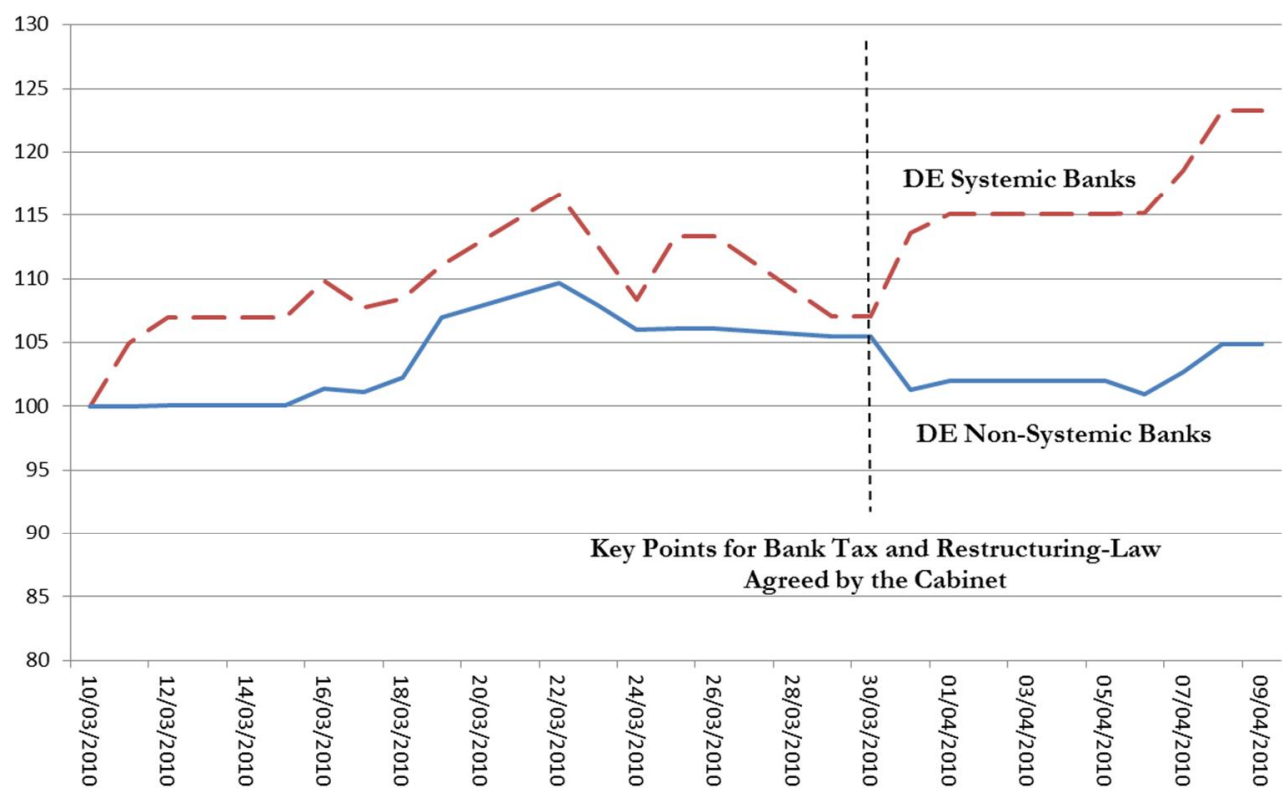

The figure shows the reaction of CDS spreads to the indicated regulatory event in Germany. The graphs show equally weighted indices for CDS spreads, starting approximately two weeks prior to the announcement of the event. The two graphs refer to systemic and non-systemic banks.

Figure 12. Swiss Too-Big-To-Fail-Regulation | Swiss CDS Spreads of Systemic Banks

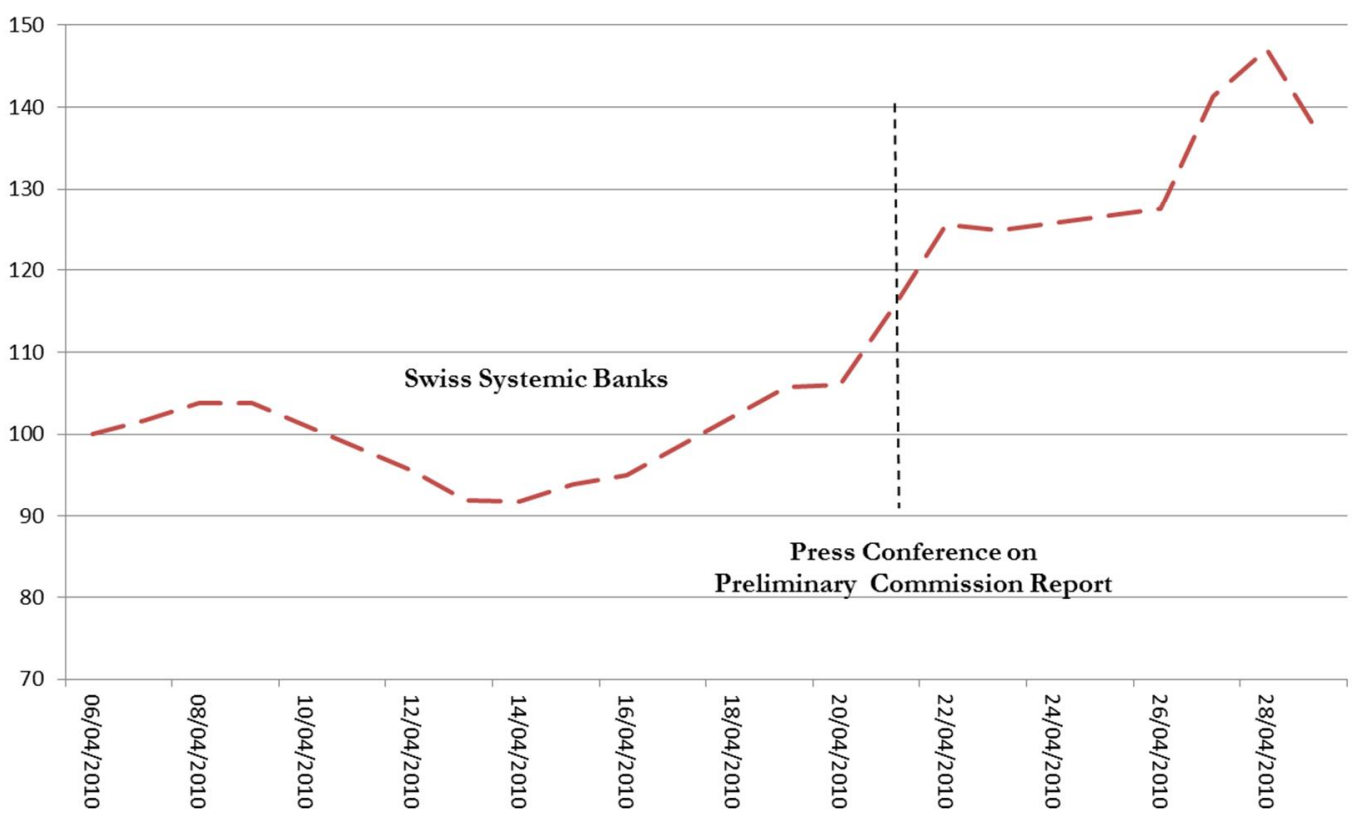

The figure shows the reaction of CDS spreads to the indicated regulatory event in Switzerland. The graph shows an equally weighted index for CD S spreads, starting approximately two weeks prior to the announcement of the event. The graphs refers to systemic banks. 
Table 2. Summary Statistics

\section{Stock Returns}

Variable/Bank Name

Bank of America

Bank of New York Mellon

Capital One Financial

Citigroup

Goldman Sachs Group

JP Morgan Chase

Metlife

Morgan Stanle

U.S. Bankcorp

Wells Fargo

Barclays

HSBC

Lloyds Banking Group

Royal Bank of Scotland

Standard Chartered

Aareal Bank

Commerzbank

Deutsche Bank

Deutsche Postbank

IKB

Bank Sarasin

Banque Cantonale de Genève

Banque Cantonale Vaudoise

Credit Suisse

Luzerner Kantonalbank

St.Galler Kantonalbank

UBS

Zuger Kantonalbank

Total Observations Stocks
Obs. Mean Std. Dev. Min Max Country Investment Bank Systemic Bank

$\begin{array}{llllll}430 & 0.0019 & 0.0643 & -0.2897 & 0.3527 & \text { US }\end{array}$

$\begin{array}{llllll}430 & 0.0004 & 0.0376 & 0.1725 & 0.2105 & \text { US }\end{array}$

$\begin{array}{llllll}430 & 0.0022 & 0.0568 & -0.2504 & 0.2643 & \text { US }\end{array}$

$\begin{array}{llllll}430 & 0.0005 & 0.0656 & -0.3902 & 0.3810 & \text { US }\end{array}$

$\begin{array}{llllll}430 & 0.0019 & 0.0350 & -0.1896 & 0.1807 & \text { US }\end{array}$

$\begin{array}{llllll}430 & 0.0014 & 0.0443 & -0.2073 & 0.2510 & \text { US }\end{array}$

$\begin{array}{llllll}430 & 0.0020 & 0.0503 & -0.2305 & 0.2245 & \text { US }\end{array}$

$\begin{array}{llllll}430 & 0.0022 & 0.0456 & -0.2305 & 0.2870 & \text { US }\end{array}$

$\begin{array}{llllll}430 & 0.0007 & 0.0450 & -0.1817 & 0.2284 & \text { US }\end{array}$

$\begin{array}{llllll}430 & 0.0013 & 0.0557 & -0.2382 & 0.3170 & \text { US }\end{array}$

$\begin{array}{lllllll}572 & -0.0010 & 0.0275 & -0.1147 & 0.1618 & \text { UK }\end{array}$

$\begin{array}{lllllll}572 & 0.0001 & 0.0157 & -0.0598 & 0.0667 & \text { UK }\end{array}$

$\begin{array}{llllll}572 & -0.0003 & 0.0296 & -0.1019 & 0.1395 & \text { UK }\end{array}$

$\begin{array}{lllllll}572 & -0.0005 & 0.0310 & -0.1232 & 0.1374 & \text { UK }\end{array}$

$\begin{array}{llllll}572 & 0.0005 & 0.0193 & -0.0752 & 0.1167 & \text { UK }\end{array}$

$\begin{array}{llllll}332 & 0.0019 & 0.0303 & -0.0832 & 0.1425 & \mathrm{DE}\end{array}$

$\begin{array}{llllll}332 & 0.0002 & 0.0237 & -0.0900 & 0.1193 & \mathrm{DE}\end{array}$

$\begin{array}{llllll}332 & -0.0002 & 0.0219 & -0.0727 & 0.1286 & \mathrm{DE}\end{array}$

$\begin{array}{lllllll}332 & 0.0002 & 0.0189 & -0.0782 & 0.0820 & \mathrm{DE}\end{array}$

$\begin{array}{lllllll}332 & 0.0014 & 0.0460 & -0.1228 & 0.5500 & \mathrm{DE}\end{array}$

$\begin{array}{lllllll}562 & 0.0009 & 0.0145 & -0.0776 & 0.0606 & \mathrm{CH}\end{array}$

$\begin{array}{llllll}562 & 0.0002 & 0.0096 & -0.0393 & 0.0537 & \mathrm{CH}\end{array}$

$\begin{array}{lllllll}562 & 0.0006 & 0.0148 & -0.0631 & 0.0608 & \mathrm{CH}\end{array}$

$\begin{array}{lllllll}562 & 0.0000 & 0.0199 & -0.0740 & 0.0882 & \mathrm{CH}\end{array}$

$\begin{array}{lllllll}562 & 0.0006 & 0.0074 & -0.0260 & 0.0340 & \mathrm{CH}\end{array}$

$\begin{array}{lllllll}562 & 0.0004 & 0.0094 & -0.0380 & 0.0451 & \mathrm{CH}\end{array}$

$\begin{array}{lllllll}562 & 0.0005 & 0.0220 & -0.1006 & 0.1121 & \mathrm{CH}\end{array}$

$\begin{array}{llllll}562 & 0.0007 & 0.0082 & -0.0243 & 0.0274 & \mathrm{CH}\end{array}$

\section{CDS Spread Differences}

Variable/Bank Name

Bank of America

Bank of New York Mellon

Capital One Financial

Citigroup

Goldman Sachs Group

JP Morgan Chase

Metlife

Morgan Stanley

U.S. Bankcorp

Wells Fargo

Barclays

HSBC

Lloyds Banking Group

Royal Bank of Scotland

Standard Chartered

Allianz

Commerzbank

Deutsche Bank

Bayerische Landesbank

IKB

Credit Suisse

UBS

Total Observations CDS
Obs. Mean Std. Dev. Min

Max Country Investment Bank Systemic Bank

$\begin{array}{llllllll}430 & 0.0068 & 11.0876 & -58.3081 & 60.0000 & \text { US } & \mathrm{X} & \mathrm{X}\end{array}$

$\begin{array}{lllllll}430 & -0.4268 & 25.8032 & -231.7500 & 317.2400 & \text { US } & X\end{array}$

$\begin{array}{lllll}430 & -0.4310 & 10.8233 & -49.4426 & 55.5525\end{array}$ US

$\begin{array}{llllll}430 & -0.0868 & 22.0788 & -238.8750 & 157.4899 & \text { US }\end{array}$

$\begin{array}{llllll}430 & -0.3833 & 10.5185 & -71.1074 & 47.4976 & \text { US }\end{array}$

$\begin{array}{llllll}430 & -0.0721 & 6.6029 & -29.1650 & 33.0540 & \text { US }\end{array}$

$\begin{array}{llllll}430 & -0.3714 & 24.4859 & -114.5667 & 210.4768 & \text { US }\end{array}$

$\begin{array}{llllll}430 & -0.4974 & 10.8647 & -60.0000 & 40.0000 & \text { US }\end{array}$

$\begin{array}{lllll}430 & -0.7699 & 13.8737 & -84.2519 & 113.3276\end{array}$ US

$\begin{array}{llllll}430 & -0.0011 & 9.0333 & -45.2650 & 45.8700 & \text { US }\end{array}$

$\begin{array}{llllll}572 & 0.2410 & 5.6901 & -39.7126 & 29.1990 & \text { UK }\end{array}$

$\begin{array}{llllll}572 & 0.1703 & 6.6554 & -69.3119 & 54.4810 & \text { UK }\end{array}$

$\begin{array}{llllll}572 & 0.3304 & 6.8401 & -54.5287 & 49.6035 & \text { UK }\end{array}$

$\begin{array}{llllll}572 & 0.0896 & 2.4365 & -14.9058 & 13.8877 & \text { UK }\end{array}$

$\begin{array}{llllll}572 & 0.0358 & 3.1251 & -16.4000 & 15.2800 & -\mathrm{UK}\end{array}$

$\begin{array}{llllll}332 & 0.0293 & 3.4640 & -23.2750 & 19.6855 & \text { DE }\end{array}$

$\begin{array}{llllll}332 & 0.0583 & 4.8643 & -31.3873 & 28.1716 & \mathrm{DE}\end{array}$

$\begin{array}{llllll}332 & 0.0050 & 5.4117 & -46.8648 & 20.7904 & \mathrm{DE}\end{array}$

$\begin{array}{llllll}332 & 0.2055 & 4.0363 & -27.3274 & 29.2500 & \mathrm{DE}\end{array}$

$\begin{array}{llllll}332 & -0.2335 & 11.2943 & -88.4599 & 88.5698 & \text { DE }\end{array}$

$\begin{array}{llllll}562 & -0.1226 & 5.3881 & -33.4167 & 20.9800 & \mathrm{CH}\end{array}$

$\begin{array}{llllll}562 & -0.1666 & 4.3706 & -35.3645 & 15.8504 & \mathrm{CH}\end{array}$

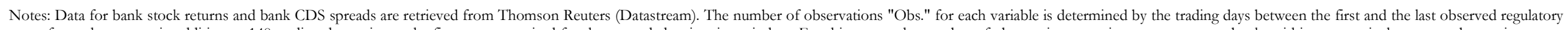

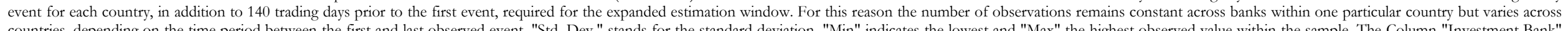

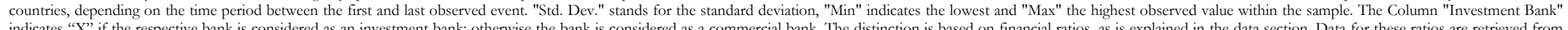

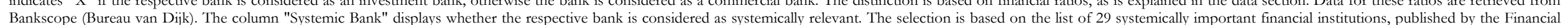
Stability Board on 4th November 2011. 
Table 3: Abnormal Returns in the United States (The D odd-Frank Act)

P-values in brackets; dependent variable: daily bank stock return (left panel) and first difference in CD S spreads (right panel)

\begin{tabular}{|c|c|c|c|c|c|c|c|c|c|c|c|}
\hline \multirow[b]{2}{*}{ Estimation Window } & & \multicolumn{5}{|c|}{ Stock Retums } & \multicolumn{5}{|c|}{ CDSSpreads } \\
\hline & & & 80 & 140 & 80 & 80 & & 80 & 140 & 80 & 80 \\
\hline Dodd-FrankAct & Date & $\begin{array}{c}\text { Average } \\
\text { Return }\end{array}$ & $\begin{array}{c}\text { Average } \\
\text { Abnormal } \\
\text { Return }\end{array}$ & $\begin{array}{c}\text { Average } \\
\text { Abnormal } \\
\text { Return }\end{array}$ & $\begin{array}{l}\text { Investment } \\
\text { vs. } \\
\text { Commercial }\end{array}$ & $\begin{array}{l}\text { Systemic vs. } \\
\text { Non- } \\
\text { Systemic }\end{array}$ & $\begin{array}{c}\text { Average } \\
\text { Return }\end{array}$ & $\begin{array}{c}\text { Average } \\
\text { Abnormal } \\
\text { Return }\end{array}$ & $\begin{array}{c}\text { Average } \\
\text { Abnormal } \\
\text { Return }\end{array}$ & $\begin{array}{l}\text { Investment } \\
\text { vs. } \\
\text { Commercial }\end{array}$ & $\begin{array}{l}\text { Systemic vs } \\
\text { Non- } \\
\text { Systemic }\end{array}$ \\
\hline O bama set to target banks with new fees & 12-Jan-10 & -1.624 & $\begin{array}{c}-0.536 \\
{[0.673]}\end{array}$ & $\begin{array}{c}-0.661 \\
{[0.617]}\end{array}$ & $\begin{array}{c}\mathbf{- 1 . 5 5} \boldsymbol{F}^{*} \\
{[0.056]}\end{array}$ & $\begin{array}{c}\mathbf{- 2 5 2} 5^{* *} \\
{[0.012]}\end{array}$ & -0.285 & $\begin{array}{c}0.170 \\
{[0.967]}\end{array}$ & $\begin{array}{c}0.666 \\
{[0.904]}\end{array}$ & $\begin{array}{c}0.068 \\
{[0.981]}\end{array}$ & $\begin{array}{c}-0.074 \\
{[0.984]}\end{array}$ \\
\hline O bama urges banks to take part in crisis costs & 15-Jan-10 & -2.187 & $\begin{array}{l}-0.386 \\
{[0.761]}\end{array}$ & $\begin{array}{l}-0.517 \\
{[0.695]}\end{array}$ & $\begin{array}{l}-0.481 \\
{[0.554]}\end{array}$ & $\begin{array}{l}-0.837 \\
{[0.407]}\end{array}$ & 3.725 & $\begin{array}{l}\text { 7.13* } \\
{[0.080]}\end{array}$ & $\begin{array}{c}7.660 \\
{[0.163]}\end{array}$ & $\begin{array}{l}-1.306 \\
{[0.651]}\end{array}$ & $\begin{array}{c}1.249 \\
{[0.736]}\end{array}$ \\
\hline Announcement of the Volcker Rule & 21-Jan-10 & -3.060 & $\begin{array}{l}-0.074 \\
{[0.953]}\end{array}$ & $\begin{array}{l}-0.177 \\
{[0.982]}\end{array}$ & $\begin{array}{c}-\mathbf{3 . 3 5} \mathbf{7}^{* * * *} \\
{[0.000]}\end{array}$ & $\begin{array}{c}\mathbf{- 2 9 4 4 * * *} \\
{[0.004]}\end{array}$ & 7.773 & $\begin{array}{c}\mathbf{8 2 2}^{* *} \\
{[0.036]}\end{array}$ & $\begin{array}{c}8.754 \\
{[0.107]}\end{array}$ & $\begin{array}{c}\mathbf{7 . 8 6 3} \text { *** } \\
{[0.006]}\end{array}$ & $\begin{array}{l}\mathbf{7 . 8 2} 2^{* *} \\
{[0.033]}\end{array}$ \\
\hline - Enlarged event window [0-1] & & -7.223 & $\begin{array}{l}-2.012 \\
{[0.261]}\end{array}$ & $\begin{array}{l}-2.161 \\
{[0.250]}\end{array}$ & $\begin{array}{c}\mathbf{- 3 8 8} / 5^{* * *} \\
{[0.001]}\end{array}$ & $\begin{array}{l}-0.916 \\
{[0.530]}\end{array}$ & 15.970 & $\begin{array}{c}16.908 \text { **** } \\
{[0.003]}\end{array}$ & $\begin{array}{c}17.992^{* *} \\
{[0.020]}\end{array}$ & $\begin{array}{c}5.289 \\
{[0.169]}\end{array}$ & $\begin{array}{c}4.022 \\
{[0.496]}\end{array}$ \\
\hline O bama promoted reform plans in New York City & 22-Apr-10 & 0.259 & $\begin{array}{c}0.466 \\
{[0.669]}\end{array}$ & $\begin{array}{c}0.762 \\
{[0.520]}\end{array}$ & $\begin{array}{c}-0.136 \\
{[0.874]}\end{array}$ & $\begin{array}{c}0.216 \\
{[0.764]}\end{array}$ & 5.103 & $\begin{array}{c}5.421 \\
{[0.115]}\end{array}$ & $\begin{array}{c}5.526 \\
{[0.168]}\end{array}$ & $\begin{array}{l}-0.676 \\
{[0.749]}\end{array}$ & $\begin{array}{c}0.275 \\
{[0.930]}\end{array}$ \\
\hline - Enlarged event window [0-1] & & 0.141 & $\begin{array}{l}-0.333 \\
{[0.829]}\end{array}$ & $\begin{array}{l}-0.064 \\
{[0.969]}\end{array}$ & $\begin{array}{l}-0.377 \\
{[0.767]}\end{array}$ & $\begin{array}{l}-1.428 \\
{[0.163]}\end{array}$ & 3.866 & $\begin{array}{l}\mathbf{8 3 6 8 ^ { * }} \\
{[0.087]}\end{array}$ & $\begin{array}{c}8.578 \\
{[0.131]}\end{array}$ & $\begin{array}{c}2.727 \\
{[0.413]}\end{array}$ & $\begin{array}{c}3.526 \\
{[0.426]}\end{array}$ \\
\hline Democrats are willing to dilute rules for swap desks & 16-May-10 & -0.206 & $\begin{array}{c}0.371 \\
{[0.736]}\end{array}$ & $\begin{array}{c}0.653 \\
{[0.590]}\end{array}$ & $\begin{array}{c}0.206 \\
{[0.825]}\end{array}$ & $\begin{array}{l}-0.800 \\
{[0.328]}\end{array}$ & 4.436 & $\begin{array}{c}0.624 \\
{[0.913]}\end{array}$ & $\begin{array}{c}0.573 \\
{[0.910]}\end{array}$ & $\begin{array}{l}\mathbf{- 5 . 8 3 * *} \\
{[0.021]}\end{array}$ & $\begin{array}{l}-5.155 \\
{[0.154]}\end{array}$ \\
\hline Reform bill passes the senate & 20-May-10 & -4.432 & $\begin{array}{l}-1.188 \\
{[0.293]}\end{array}$ & $\begin{array}{l}-0.691 \\
{[0.578]}\end{array}$ & $\begin{array}{c}0.317 \\
{[0.742]}\end{array}$ & $\begin{array}{l}-0.135 \\
{[0.874]}\end{array}$ & 10.353 & $\begin{array}{c}10.38 \mathbf{2}^{* *} \\
{[0.067]}\end{array}$ & $\begin{array}{c}\text { 1.399*** } \\
{[0.037]}\end{array}$ & $\begin{array}{c}1.962 \\
{[0.491]}\end{array}$ & $\begin{array}{c}3.109 \\
{[0.429]}\end{array}$ \\
\hline US Banks set to lose lobby fight on swaps & 13-Jun-10 & -0.121 & $\begin{array}{c}-\mathbf{2 2 0 0 8 ^ { * * } *} \\
{[0.037]}\end{array}$ & $\begin{array}{l}\mathbf{- 2 1 8 6 ^ { * }} \\
{[0.064]}\end{array}$ & $\begin{array}{l}-0.330 \\
{[0.719]}\end{array}$ & $\begin{array}{l}-0.825 \\
{[0.345]}\end{array}$ & -8.985 & $\begin{array}{l}-5.797 \\
{[0.362]}\end{array}$ & $\begin{array}{l}-5.607 \\
{[0.299]}\end{array}$ & $\begin{array}{c}0.805 \\
{[0.771]}\end{array}$ & $\begin{array}{c}3.534 \\
{[0.312]}\end{array}$ \\
\hline Consensuns between parties - the dilution - & 25-Jun-10 & 2.825 & $\begin{array}{c}274^{* * *} \\
{[0.009]}\end{array}$ & $\begin{array}{l}\mathbf{2 7 9 6} 6^{* *} \\
{[0.014]}\end{array}$ & $\begin{array}{c}0.890 \\
{[0.325]}\end{array}$ & $\begin{array}{l}-0.105 \\
{[0.895]}\end{array}$ & -4.307 & $\begin{array}{l}-4.514 \\
{[0.489]}\end{array}$ & $\begin{array}{l}-4.532 \\
{[0.404]}\end{array}$ & $\begin{array}{l}-2.674 \\
{[0.714]}\end{array}$ & $\begin{array}{c}-2.628 \\
{[0.571]}\end{array}$ \\
\hline Summation & & -12.825 & -3.552 & -2.832 & -5.201 & -7.572 & 24.772 & 38.694 & 35.664 & 1.041 & 7.582 \\
\hline
\end{tabular}

Notes: The table shows the results from SUR regressions corresponding to the subevents for stock returns and CD S spreads, respectively, using estimation windows of 80 or 140 trading days. Each system of regressions includes 10 banks. All subevents refer to frontpage articles in the Financial Times, U.S. edition. The table displays all subevents, for which any significant reaction could be found either in equity prices or CD S spreads. The full list of results for all identified subevents can be found in the Appendix (Table A1). The number of observations ranges between 800 (corresponding to an estimation window of 80 days) and 1400 (140 trading days). All estimations are using balanced samples. If the estimation window contains another subevent, this is "dummied out" by including the corresponding event dummies (including pre- and post-event dummies). Through an iteration procedure, we make sure that all estimation windows contain exactly the given number of observations (not including other events). The regressions in the left panel use daily stock returns of banks as dependent variable (in percentage points), those in the right panel use daily first differences in bank CD S spreads (in basis points). The first number column in each panel displays the unadjusted averac rem of all banks within the sample at the rective event day. "Average Abnorma Retums" refer to the averne abnormal return of all banks at the mespective event day. The Colum "Investment vs. Commerial" shows the differn " share of totat 29 brackets cor

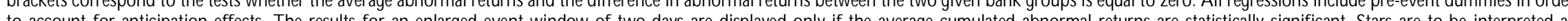
follows: *** significant at 1 percent, ** significant at 5 percent * significant at 10 percent. 
Table 4. Abnormal Returns due to Spillover Effects of United States Reform Events

P-Values in brackets; dependent variable: daily bank stock return (left panel) and first difference in CD S spreads (right panel)

\begin{tabular}{|c|c|c|c|c|c|c|c|c|c|c|c|}
\hline \multirow[b]{2}{*}{ Estimation window } & \multicolumn{6}{|c|}{ Stock Retums } & \multicolumn{4}{|c|}{ CDS Spreads } & \\
\hline & & & 80 & 140 & 80 & 80 & & 80 & 140 & 80 & \\
\hline United Kingdom & Date & $\begin{array}{l}\text { Average } \\
\text { Return }\end{array}$ & $\begin{array}{l}\text { Average } \\
\text { Abnormal } \\
\text { Return }\end{array}$ & $\begin{array}{c}\text { Average } \\
\text { Abnormal } \\
\text { Return }\end{array}$ & $\begin{array}{l}\text { Investment } \\
\text { vs. } \\
\text { Commercial }\end{array}$ & $\begin{array}{l}\text { Systemic vs. } \\
\text { Non- } \\
\text { Systemic }\end{array}$ & $\begin{array}{l}\text { Average } \\
\text { Return }\end{array}$ & $\begin{array}{c}\text { Average } \\
\text { Abnormal } \\
\text { Return } \\
\end{array}$ & $\begin{array}{c}\text { Average } \\
\text { Abnormal Return }\end{array}$ & $\begin{array}{l}\text { Investment vs. } \\
\text { Commercial }\end{array}$ & $\begin{array}{l}\text { Systemic vs. } \\
\text { Non- } \\
\text { Systemic }\end{array}$ \\
\hline Announcement of the Volcker Rule & 21-Jan-10 & -5.010 & $\begin{array}{c}-4.801^{* *} \\
{[0.022]}\end{array}$ & $\begin{array}{c}\mathbf{- 5 . 1 4 1 * *} \\
{[0.016]}\end{array}$ & $\begin{array}{l}-2.246 \\
{[0.202]}\end{array}$ & $\begin{array}{c}0.527 \\
{[0.757]}\end{array}$ & 1.978 & $\begin{array}{c}1.940 \\
{[0.344]}\end{array}$ & $\begin{array}{c}2.334 \\
{[0.372]}\end{array}$ & $\begin{array}{c}0.842 \\
{[0.628]}\end{array}$ & $\begin{array}{c}2.349 \\
{[0.304]}\end{array}$ \\
\hline Consensuns between parties - the dilution - & 25-Jun-10 & -0.961 & $\begin{array}{l}-1.363 \\
{[0.558]}\end{array}$ & $\begin{array}{l}-1.362 \\
{[0.539]}\end{array}$ & $\begin{array}{l}-1.751 \\
{[0.202]}\end{array}$ & $\begin{array}{l}-3.489 * * \\
{[0.021]}\end{array}$ & 2.132 & $\begin{array}{c}2.017 \\
{[0.766]}\end{array}$ & $\begin{array}{c}1.823 \\
{[0.734]}\end{array}$ & $\begin{array}{c}2.825 \\
{[0.566]}\end{array}$ & $\begin{array}{c}2.678 \\
{[0.700]}\end{array}$ \\
\hline $\begin{array}{l}\text { Dodd-Frank Act signed by O bama } \\
\text { Germany }\end{array}$ & 21-Jul-10 & 0.656 & $\begin{array}{c}0.568 \\
{[0.808]}\end{array}$ & $\begin{array}{c}0.538 \\
{[0.814]}\end{array}$ & $\begin{array}{c}-0.100 \\
{[0.944]}\end{array}$ & $\begin{array}{c}0.587 \\
{[0.697]}\end{array}$ & -3.402 & $\begin{array}{c}1.544 \\
{[0.812]}\end{array}$ & $\begin{array}{c}1.433 \\
{[0.792]}\end{array}$ & $\begin{array}{c}1.411 \\
{[0.769]}\end{array}$ & $\begin{array}{c}2.034 \\
{[0.762]}\end{array}$ \\
\hline Announcement of the Volcker Rule & 21-Jan-10 & -2.510 & $\begin{array}{l}-1.962 \\
{[0.369]}\end{array}$ & $\begin{array}{l}-2.566 \\
{[0.307]}\end{array}$ & - & $\begin{array}{c}1.534 \\
{[0.250]}\end{array}$ & 1.608 & $\begin{array}{c}1.927 \\
{[0.404]}\end{array}$ & $\begin{array}{c}2.294 \\
{[0.450]}\end{array}$ & - & $\begin{array}{l}-0.451 \\
{[0.864]}\end{array}$ \\
\hline Consensuns between parties - the dilution - & 25-Jun-10 & -0.030 & $\begin{array}{c}-0.093 \\
{[0.956]}\end{array}$ & $\begin{array}{c}-0.955 \\
{[0.962]}\end{array}$ & - & $\begin{array}{c}0.266 \\
{[0.856]}\end{array}$ & 5.784 & $\begin{array}{c}5.413 \\
{[0.417]}\end{array}$ & $\begin{array}{c}5.486 \\
{[0.302]}\end{array}$ & - & $\begin{array}{c}6.495 \\
{[0.164]}\end{array}$ \\
\hline $\begin{array}{l}\text { D odd-Frank Act signed by Obama } \\
\text { Switzerland }\end{array}$ & 21-Jul-10 & -0.045 & n.a. & n.a. & - & n.a. & -2.482 & $\begin{array}{c}0.230 \\
{[0.973]}\end{array}$ & $\begin{array}{c}0.367 \\
{[0.945]}\end{array}$ & - & $\begin{array}{c}0.936 \\
{[0.840]}\end{array}$ \\
\hline Announcement of the Volcker Rule & 21-Jan-10 & -0.333 & $\begin{array}{c}-1.346^{* *} \\
{[0.043]}\end{array}$ & $\begin{array}{l}\mathbf{- 1 . 4 9 4 *} \\
{[0.052]}\end{array}$ & - & $\begin{array}{c}-4.54^{* * *} \\
{[0.006]}\end{array}$ & 1.255 & $\begin{array}{c}1.665 \\
{[0.612]}\end{array}$ & $\begin{array}{c}2.176 \\
{[0.619]}\end{array}$ & - & n.a. \\
\hline Consensuns between parties - the dilution - & 25-Jun-10 & -0.165 & $\begin{array}{l}-0.181 \\
{[0.827]}\end{array}$ & $\begin{array}{l}-0.195 \\
{[0.789]}\end{array}$ & - & $\begin{array}{l}-1.073 \\
{[0.569]}\end{array}$ & -8.265 & $\begin{array}{l}-0.367 \\
{[0.961]}\end{array}$ & $\begin{array}{l}-0.338 \\
{[0.995]}\end{array}$ & - & n.a. \\
\hline D odd-Frank Act signed by O bama & 21-Jul-10 & -0.008 & $\begin{array}{l}-0.015 \\
{[0.985]}\end{array}$ & $\begin{array}{l}-0.003 \\
{[0.998]}\end{array}$ & - & $\begin{array}{c}0.233 \\
{[0.896]}\end{array}$ & -6.840 & n.a. & n.a. & - & n.a. \\
\hline
\end{tabular}

Notes: The table shows the results from SUR regressions corresponding to the subevents for stock retums and CDS spreads, respectively, using estimation windows of 80 or 140 trading days. All subevents refer to a simultaneous publication of a frontpage article in the U.S., U.K. and E urope edition of the Financial Times. In the case of stock returns each system of regressions includes 8 banks. In case of the United Kingdom each system of regressions includes 5 banks. The number of observations ranges between 400 (corresponding to an estimation window of 80 days) and 700 ( 140 trading days). In the case of $G$ ermany each system of regressions includes 5 banks. The number of observations ranges between 400 (corresponding to an estimation window of 80 days) and 700 (140 trading days). For Switzerland the samples on stock returns and CDS spreads have different sizes. In case of stock returns each system of regressions includes 8 banks. The number of observations for stock returns ranges between 640 (corresponding to an estimation whiow of 80 days) and 1120 (140 trading days). If the estimation window contains another subevent this is "dummied out" by including the corresponding event dummies (including pre- and post-event dummies). Through an iteration procedum we make sure that all estimation windows contain exactly the given number of observations (not including other events). The regressions in the left panel use daily stock returns of banks as dependent variable (in percentage points). those in the right panel use daily first differences in bank CD S spreads (in basis points). The first number column in each panel displays the unadjusted average returm of all banks within the sample at the respective event day. "Average Abnormal Returns" refer to the average abnormal return of all banks at the respective event day. The Column "Investment vs. Commencial" shows the difference in abnormal retums of investment banks and commercial banks. The splitting is based on customer deposits as a share of total assets and non-interest income as a share of total revenue. The column "Systemic vs. Non-Systemic" displays the difference in abnormal returns of systemically relevant and non-systemically relevant banks. The latter selection is based on the list of 29 systemically relevant institutions, published by the Financial Stability Board on 4th November 2011. The tests for heterogeneity are conducted on the basis of an 80 trading days estimation window. The $p$-values in brackets correspond to the tests whether the average abnormal returns and the difference in abnormal returns between the two given bank groups is equal to zero. All regressions include pre-event dummies in order to account for anticipation effects. The results for an enlarged event window of two days are displayed only if the average cumulated abnormal returns are statistically significant. Stars are to be interpreted as follows: *** significant at 1 percent, $* *$ significant at 5 percent, $*$ significant at 10 percent. 
Table 5. Abnormal Returns in the United Kingdom (The Vickers Reform Proposals)

P-values in brackets; dependent variable: daily bank stock return (left panel) and first difference in CDS spreads (right panel)

\begin{tabular}{|c|c|c|c|c|c|c|c|c|c|c|c|}
\hline \multirow[b]{2}{*}{ Estimation window } & & \multicolumn{5}{|c|}{ Stock Retums } & \multicolumn{5}{|c|}{ CDS Spreads } \\
\hline & & & 80 & 140 & 80 & 80 & & 80 & 140 & 80 & 80 \\
\hline The Vickers Reform Proposals & Date & $\begin{array}{c}\text { Average } \\
\text { Return }\end{array}$ & $\begin{array}{c}\text { Average } \\
\text { Abnormal } \\
\text { Return }\end{array}$ & $\begin{array}{c}\text { Average } \\
\text { Abnormal } \\
\text { Return }\end{array}$ & $\begin{array}{l}\text { Investment } \\
\text { vs. } \\
\text { Commercial }\end{array}$ & $\begin{array}{l}\text { Systemic } \\
\text { vs. Non- } \\
\text { Systemic }\end{array}$ & $\begin{array}{c}\text { Average } \\
\text { Return }\end{array}$ & $\begin{array}{c}\text { Average } \\
\text { Abnormal } \\
\text { Return }\end{array}$ & $\begin{array}{c}\text { Average } \\
\text { Abnormal } \\
\text { Return }\end{array}$ & $\begin{array}{l}\text { Investment } \\
\text { vs. } \\
\text { Commercial }\end{array}$ & $\begin{array}{l}\text { Systemic vs. } \\
\text { Non- } \\
\text { Systemic }\end{array}$ \\
\hline Spill-O ver-Effect: Announcement of the Volcker Rule & 21-Jan-10 & -5.010 & $\begin{array}{c}\mathbf{- 4 . 8 0 1 * *} \\
{[0.022]}\end{array}$ & $\begin{array}{c}-5.141^{* *} \\
{[0.016]}\end{array}$ & $\begin{array}{l}-2.246 \\
{[0.202]}\end{array}$ & $\begin{array}{c}0.527 \\
{[0.757]}\end{array}$ & 1.978 & $\begin{array}{c}1.940 \\
{[0.344]}\end{array}$ & $\begin{array}{c}2.334 \\
{[0.372]}\end{array}$ & $\begin{array}{c}0.842 \\
{[0.628]}\end{array}$ & $\begin{array}{c}2.349 \\
{[0.304]}\end{array}$ \\
\hline Spillover effect: Consensuns between parties - the dilution - & 25-Jun-10 & -0.961 & $\begin{array}{l}-1.363 \\
{[0.558]}\end{array}$ & $\begin{array}{l}-1.362 \\
{[0.539]}\end{array}$ & $\begin{array}{l}-1.175 \\
{[0.202]}\end{array}$ & $\begin{array}{c}-3.489 * * \\
{[0.021]}\end{array}$ & 2.132 & $\begin{array}{c}2.017 \\
{[0.766]}\end{array}$ & $\begin{array}{c}1.823 \\
{[0.734]}\end{array}$ & $\begin{array}{c}2.825 \\
{[0.566]}\end{array}$ & $\begin{array}{c}2.678 \\
{[0.700]}\end{array}$ \\
\hline Barclays warns to levae U.K. in case of a bank break-up & 05-Aug-10 & -0.669 & $\begin{array}{l}-0.833 \\
{[0.745]}\end{array}$ & $\begin{array}{l}-1.025 \\
{[0.654]}\end{array}$ & $\begin{array}{c}-3.004^{* *} \\
{[0.048]}\end{array}$ & $\begin{array}{l}-0.668 \\
{[0.658]}\end{array}$ & 4.150 & $\begin{array}{c}3.995 \\
{[0.576]}\end{array}$ & $\begin{array}{c}4.056 \\
{[0.495]}\end{array}$ & $\begin{array}{c}4.571 \\
{[0.388]}\end{array}$ & $\begin{array}{c}5.239 \\
{[0.483]}\end{array}$ \\
\hline Big banks strike back at call for break-up & 26-Jan-11 & -1.011 & $\begin{array}{l}-0.660 \\
{[0.680]}\end{array}$ & $\begin{array}{l}-1.292 \\
{[0.466]}\end{array}$ & $\begin{array}{l}-1.802 \\
{[0.180]}\end{array}$ & $\begin{array}{l}-1.690 \\
{[0.297]}\end{array}$ & -0.601 & $\begin{array}{l}-0.567 \\
{[0.858]}\end{array}$ & $\begin{array}{l}-0.336 \\
{[0.915]}\end{array}$ & $\begin{array}{l}\mathbf{4 . 2 7 1 * *} \\
{[0.023]}\end{array}$ & $\begin{array}{l}5.386^{*} \\
{[0.080]}\end{array}$ \\
\hline Equity Requirements proposal (better than expected) & 11-Apr-11 & 0.799 & $\begin{array}{c}0.621 \\
{[0.632]}\end{array}$ & $\begin{array}{c}0.594 \\
{[0.659]}\end{array}$ & $\begin{array}{c}2.693^{* *} \\
{[0.014]}\end{array}$ & $\begin{array}{c}1.827 \\
{[0.177]}\end{array}$ & -1.415 & $\begin{array}{l}-1.255 \\
{[0.703]}\end{array}$ & $\begin{array}{l}-1.221 \\
{[0.684]}\end{array}$ & $\begin{array}{l}-0.329 \\
{[0.875]}\end{array}$ & $\begin{array}{l}-0.945 \\
{[0.771]}\end{array}$ \\
\hline Fear that foreign banks take advantage of tough UK regulation & 17-Apr-11 & -2.231 & $\begin{array}{l}-0.425 \\
{[0.741]}\end{array}$ & $\begin{array}{l}-0.444 \\
{[0.740]}\end{array}$ & $\begin{array}{l}-1.450 \\
{[0.180]}\end{array}$ & $\begin{array}{l}-1.037 \\
{[0.438]}\end{array}$ & 9.109 & $\begin{array}{c}\text { 9.431*** } \\
{[0.003]}\end{array}$ & $\begin{array}{c}\text { 9.312*** } \\
{[0.002]}\end{array}$ & $\begin{array}{c}4.625^{* *} \\
{[0.024]}\end{array}$ & $\begin{array}{c}3.408 \\
{[0.291]}\end{array}$ \\
\hline O sborne's pre-approval of the ringfencing approach & 15-Jun-11 & -1.743 & $\begin{array}{l}-1.600 \\
{[0.144]}\end{array}$ & $\begin{array}{l}-1.667 \\
{[0.189]}\end{array}$ & $\begin{array}{l}-0.943 \\
{[0.279]}\end{array}$ & $\begin{array}{l}-0.630 \\
{[0.587]}\end{array}$ & 4.391 & $\begin{array}{l}4.248^{*} \\
{[0.085]}\end{array}$ & $\begin{array}{c}4.251 \\
{[0.138]}\end{array}$ & $\begin{array}{c}1.320 \\
{[0.477]}\end{array}$ & $\begin{array}{c}3.652 \\
{[0.105]}\end{array}$ \\
\hline Postponement of the reform to 2015 (post-election period) & 31-Aug-11 & 3.164 & $\begin{array}{l}-3.983 \\
{[0.110]}\end{array}$ & $\begin{array}{l}3.766^{*} \\
{[0.055]}\end{array}$ & $\begin{array}{c}0.317 \\
{[0.847]}\end{array}$ & $\begin{array}{c}1.005 \\
{[0.594]}\end{array}$ & -8.649 & $\begin{array}{c}-10.011^{* *} \\
{[0.036]}\end{array}$ & $\begin{array}{c}\mathbf{- 9 . 2 8 6 * *} \\
{[0.019]}\end{array}$ & $\begin{array}{c}\mathbf{- 8 . 0 7}^{* * *} \\
{[0.005]}\end{array}$ & $\begin{array}{l}-5.32^{*} \\
{[0.099]}\end{array}$ \\
\hline - Enlarged event window [0-1] & & 7.366 & $\begin{array}{r}\mathbf{8 . 9 7 2 * *} \\
{[0.013]}\end{array}$ & $\begin{array}{c}\text { 8.538*** } \\
{[0.002]}\end{array}$ & $\begin{array}{l}5.408^{* * *} \\
{[0.022]}\end{array}$ & $\begin{array}{c}\mathbf{5 . 8 7 9 * *} \\
{[0.030]}\end{array}$ & -14.991 & $\begin{array}{c}-17.73 * * * \\
{[0.009]}\end{array}$ & $\begin{array}{c}-16.27 * * * \\
{[0.004]}\end{array}$ & $\begin{array}{c}\mathbf{- 1 4 . 2 4 6 * * *} \\
{[0.001]}\end{array}$ & $\begin{array}{c}\mathbf{- 9 . 0 6 9 * *} \\
{[0.046]}\end{array}$ \\
\hline Publication of the Vickers Report & 12-Sep-11 & -1.547 & $\begin{array}{l}-1.120 \\
{[0.657]}\end{array}$ & $\begin{array}{l}-1.369 \\
{[0.495]}\end{array}$ & $\begin{array}{l}-0.317 \\
{[0.847]}\end{array}$ & $\begin{array}{l}-2.756 \\
{[0.138]}\end{array}$ & 15.138 & $\begin{array}{c}\text { 13.738*** } \\
{[0.004]}\end{array}$ & $\begin{array}{c}14.455^{* * *} \\
{[0.000]}\end{array}$ & $\begin{array}{c}2.493 \\
{[0.382]}\end{array}$ & $\begin{array}{l}5.633^{*} \\
{[0.075]}\end{array}$ \\
\hline Summation & & -5.007 & -1.211 & -3.167 & -2.837 & -2.038 & 19.892 & 15.817 & 18.405 & 6.359 & 18.330 \\
\hline
\end{tabular}

Notes: The table shows the results from SUR regressions corresponding to the subevents for stock returns and CD S spreads, respectively, using estimation windows of 80 or 140 trading days. Each system of regressions includes 5 banks. All subevents refer to frontpage articles in the Financial Times, U.K. edition. The table displays all subevents, for which any significant reaction could be found either in equity prices or CD S spreads. The full list of results for all identified subevents can be found in the Appendix (Table A2). The number of observations ranges between 400 (corresponding to an estimation window of 80 days) and 700 (140 trading days). All estimations are using balanced samples. If the estimation window contains another subevent, this is "dummied out" by including the corresponding event dummies (including pre- and post-event dummies). Through an iteration procedure, we make sure that all estimation windows contain exactly the given number of observations (not including other events). The regressions in the left panel use daily stock returns of banks as dependent variable (in percentage points), those in the right panel use daily first differences in bank CDS spreads (in basis points). The first number column in each panel displays the unadjusted average return of all banks within the variable (in percentage points), those in the right panel use daily first differences in bank CD S spreads (in basis points). The first number column in each panel displays the unadjusted average return of all banks within the
sample at the respective event day. "Average Abnormal Returns" refer to the average abnormal return of all banks at the respective event day. The Column "Investment vs. Commercial" shows the difference in abnormal returns of investment banks and commercial banks. The splitting is based on customer deposits as a share of total assets and non-interest income as a share of total revenue. The column "Systemic vs. Non-Systemic" displays the difference in abnormal returns of systemically relevant and non-systemically relevant banks. The latter selection is based on the list of 29 systemically relevant institutions, published by the Financial Stability Board on 4th November 2011. The tests for heterogeneity are conducted on the basis of an 80 trading days estimation window. The p-values in brackets correspond to the tests whether the average abnormal returns and the difference in abnormal returns between the two given bank groups is equal to zero. All regressions include pre-event dummies in order to account for anticipation effects. The results for an enlarged event window of two days are displayed only if the average cumulated abnormal returns are statistically significant. Stars are to be interpreted as follows: *** significant at 1 percent, ** significant at 5 percent, * significant at 10 percent. 
Table 6. Abnormal Returns in G ermany (Bank Tax and Restructuring-Law)

P-Values in brackets; dependent variable: daily bank stock return (left panel) and first difference in CD S spreads (right panel)

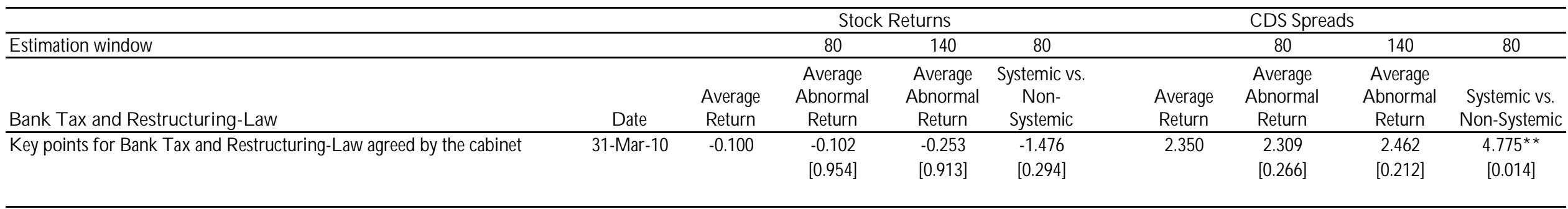

Notes: The table shows the result from a SUR regression corresponding to the subevent for stock returns and CD S spreads, respectively, using estimation windows of 80 or 140 trading days. Each system of regressions includes 5 banks. The subevent refers to a frontpage article of the Börsenzeitung. The table displays the subevents, for which any significant reaction could be found either in equity prices or $\mathrm{CD} S$ spreads. The full list of results for all identified subevents can be found in the Appendix (Table A3). The number of observations ranges between 400 (corresponding to an estimation window of 80 days) and 700 (140 trading days). All estimations are using balanced samples. If the estimation window contains another subevent, this is "dummied out" by including the corresponding event dummies (including preand post-event dummies). Through an iteration procedure, we make sure that all estimation windows contain exactly the given number of observations (not including other events). The regressions in the left panel use daily stock returns of banks as dependent variable (in percentage points), those in the right panel use daily first differences in bank CD S spreads (in basis points). The first number column in each panel displays the unadjusted average return of all banks within the sample at the respective event day. "Average Abnormal Returns" refer to the average abnormal return of all banks at the respective event day. The column "Systemic vs. Non-Systemic" displays the difference in abnormal returns of systemically relevant and non-systemically relevant banks. The selection is based on the list of 29 systemically relevant institutions, published by the Financial Stability Board on 4th November 2011. The test for heterogeneity is conducted on the basis of an 80 trading days estimation window. The p-values in brackets correspond to the tests whether the average abnormal returns and the difference in abnormal returns between the two given bank groups is equal to zero. All regressions include pre-event dummies in order to account for anticipation effects. Stars are to be interpreted as follows: *** significant at 1 percent, ** significant at 5 percent, * significant at 10 percent. 
Table 7. Abnormal Returns in Switzerland (Too-Big-To-Fail-Regulation)

P-values in brackets; dependent variable: daily bank stock return (left panel) and first difference in CD S spreads (right panel)

\begin{tabular}{|c|c|c|c|c|c|c|c|c|}
\hline & & \multicolumn{4}{|c|}{ Stock Retums } & \multicolumn{3}{|c|}{ CDSSpreads } \\
\hline Estimation window & & & 80 & 140 & 80 & & 80 & 140 \\
\hline Too-Big-To-Fail-Regulation & Date & $\begin{array}{l}\text { Average } \\
\text { Return }\end{array}$ & $\begin{array}{l}\text { Average abnormal } \\
\text { Return }\end{array}$ & $\begin{array}{c}\text { Average } \\
\text { abnormal Return }\end{array}$ & $\begin{array}{l}\text { Systemic vs. } \\
\text { Non-Systemic }\end{array}$ & $\begin{array}{l}\text { Average } \\
\text { Return }\end{array}$ & $\begin{array}{l}\text { Avergae abnormal } \\
\text { Return }\end{array}$ & $\begin{array}{l}\text { Avergae abnormal } \\
\text { Return }\end{array}$ \\
\hline Spillover-Effect: Announcement of the Volcker Rule & 21-Jan-10 & -0.333 & $\begin{array}{c}\mathbf{- 1 3 4 6}^{* *} \\
{[0.043]}\end{array}$ & $\begin{array}{c}\mathbf{- 1 . 4 9} \mathbf{4}^{*} \\
{[0.052]}\end{array}$ & $\begin{array}{c}-\mathbf{4 5} \text { (**** } \\
{[0.006]}\end{array}$ & 1.255 & $\begin{array}{c}1.665 \\
{[0.612]}\end{array}$ & $\begin{array}{c}2.176 \\
{[0.619]}\end{array}$ \\
\hline Press conference on preliminary too-big-to-fail-report & 22-Apr-10 & -1.199 & $\begin{array}{l}-0.959 \\
{[0.157]}\end{array}$ & $\begin{array}{l}-1.087 \\
{[0.158]}\end{array}$ & $\begin{array}{l}-2.067 \\
{[0.181]}\end{array}$ & 9.953 & $\begin{array}{c}\text { 9.994*** } \\
{[0.002]}\end{array}$ & $\begin{array}{c}\mathbf{9 . 9 5 3}^{* * * *} \\
{[0.003]}\end{array}$ \\
\hline - Enlarged event window [0-1] & & -0.204 & $\begin{array}{c}0.036 \\
{[0.970]}\end{array}$ & $\begin{array}{l}-0.192 \\
{[0.861]}\end{array}$ & $\begin{array}{l}-0.142 \\
{[0.926]}\end{array}$ & 4.623 & $\begin{array}{l}\mathbf{9 . 4 8} 7^{* *} * \\
{[0.039]}\end{array}$ & $\begin{array}{l}\mathbf{9 . 4 0 6} \mathbf{6}^{* *} \\
{[0.045]}\end{array}$ \\
\hline Summation & & -1.532 & -2.305 & -2.581 & -6.607 & 11.208 & 11.659 & 12.172 \\
\hline
\end{tabular}

Notes: The table shows the results from SUR regressions corresponding to the subevents for stock returns and CDS spreads, respectively, using estimation windows of 80 or 140 trading days. All subevents refer to frontpage articles in Neue Zürcher Zeitung (NZZ). The table displays the subevents, for which any significant reaction could be found either in equity prices or CD S spreads. The full list of results for all identified subevents can be found in the Appendix (Table 4). In case of stock returns each system of regressions includes 8 banks. The number of observations for stock returns ranges between 640 (corresponding to an estimation window of 80 days) and 1120 (140 trading days). In case of CD S spreads each system of regressions includes 2 banks for reasons of availability. The number of observations for CD S spreads ranges between 160 (corresponding to an estimation window of 80 days) and 280 (140 trading days). If the estimation window contains another subevent, this is "dummied out" by including the corresponding event dummies (including pre- and post-event dummies). Through an iteration procedure, we make sure that all estimation windows contain exactly the given number of observations (not including other events). The regressions in the left panel use daily stock returns of banks as dependent variable (in percentage points), those in the right panel use daily first differences in bank CD S spreads (in basis points). The first number column in each panel displays the unadjusted average return of all banks within the sample at the respective event day. "Average Abnormal Returns" refer to the average abnormal return of all banks at the respective event day. The column "Systemic vs. Non-Systemic" displays the difference in abnormal returns of systemically relevant and non-systemically relevant banks. The latter selection is based on the list of 29 systemically relevant institutions, published by the Financial Stability Board on 4 th November 2011 . The tests for heterogeneity are conducted on the basis of an 80 trading days estimation window. The p-values in brackets correspond to the tests whether the average abnormal returns and the difference in abnormal returns between the two given bank groups is equal to zero. All regressions include pre-event dummies in order to account for anticipation effects. The results for an enlarged event window of two days are displayed only if the average cumulated abnormal returns are statistically significant. Stars are to be interpreted as follows: *** significant at 1 percent, ** significant at 5 percent, $*$ significant at 10 percent. 
A.1. Subevents according to Frontpage Articles

\begin{tabular}{|c|c|c|c|c|}
\hline Subevent Name & Subevent Date & Frontpage Headline & \begin{tabular}{l|l} 
Newspaper & Edition \\
\end{tabular} & Date published \\
\hline \multicolumn{5}{|l|}{ United States | Dodd Frank Act } \\
\hline Blueprint of the reform bill presented by Obama & 17-Jun-09 & "Companies face regulatory revamp" & FT | US edition & 18-Jun-09 \\
\hline Geithner calls for detailed living will plans & 02-Sep-09 & "Tax Threat to banks in 'living wills' plan" & FT | US edition & 03-Sep-09 \\
\hline Obama's Speech: Wall Street must change & 14-Sep-09 & "Obama: Wallstreet must Change" & FT | US edition & 15-Sep-09 \\
\hline Reform bill entered the house & 11-Dec-09 & "Finance regulation bill passed the house" & FT | US edition & 12-Dec-09 \\
\hline Obama set to target banks with new fees & 12-Jan-10 & "Obama set to target banks with new fees" & FT | US edition & 12-Jan-10 \\
\hline Obama urges banks to take part in crisis costs & 14-Jan-10 & "Obama vow on crisis cash" & FT | US edition & 15-Jan-10 \\
\hline Announcement of the Volcker Rule & 21-Jan-10 & "Obama hammers the banks" & FT | US edition & 22-Jan-10 \\
\hline Dodd urges republicans not to dilute the reform & 14-Mar-10 & "Dodd set for finance reform bill push" & FT | US edition & 15-Mar-10 \\
\hline Obama promoted reform plans in New York City & 22-Apr-10 & "Obama presses Wall St on reform" & FT | US edition & 23-Apr-10 \\
\hline Democrats are willing to dilute rules for swap desks & 16-May-10 & "Democrats eye deal on financial reform bill" & FT | US edition & 17-May-10 \\
\hline Reform bill passes the senate & 20-May-10 & "Democrats close in on financial reform bill" & FT | US edition & 22-May-10 \\
\hline Banks set to lose lobby fight on swaps & 13-Jun-10 & "US banks set to lose lobby fight on swaps" & FT | US edition & 14-Jun-10 \\
\hline Consensuns between parties - the dilution - & 25-Jun-10 & "Way clear for radical overhaul of Wall St" & FT $\mid$ US edition & 26-Jun-10 \\
\hline Required votes for the bill achieved & 15-Jul-10 & "Wall St crackdown passed by the senate" & FT | US edition & 16-Jul-10 \\
\hline Dodd-Frank Act signed by Obama & 21-Jul-10 & "Obama signs bill to overhaul Wall Street" & FT | US edition & 22-Jul-10 \\
\hline
\end{tabular}

\section{United Kingdom | Vickers Reform Proposals}

Spillover effect: Announcement of the Volcker Rule

21-Jan-10

16-Jun-10

25-Jun-11

05-Aug-10

18-Jan-11

26-Jan-11

06-Mar-11

30-Mar-11

08-Apr-11

11-Apr-11

17-Apr-11

15-Jun-11

31-Aug-11

12-Sep-11

08-Mar-10

21-Mar-10

31-Mar-10

25-Aug-10

19-Nov-10
04-Nov-09

21-Jan-10

23-Mar-10

22-Apr-10

07-Sep-10

13-Sep-10

04-Oct-10

21-Dec-10

04-Apr-11

15-Jun-11
"Obama hammers the banks"

"FSA to be abolished in Osborne shake-up"

"Way clear for radical overhaul of Wall St"

"Barclays warns on break-up of banks"

"Vickers to put banks on notice"

"Big banks strike back at calls for break-up"

"Osborne backs capital shake-up"

"Push for banks peace deal"

"Osborne welcomes bank reforms"

"Vickers puts Lloyds in line of fire"

"Loophole fears over Vickers bank rules"

"Osborne to endorse 'ringfence' for banks"

"Banks to avoid big shake-up until 2015"

"Vickers plan shakes up City"
FT | UK edition

FT | UK edition

FT | UK edition

FT | UK edition

FT | UK edition

FT | UK edition

FT | UK edition

FT | UK edition

FT | UK edition

FT | UK edition

FT | UK edition

FT | UK edition

FT | UK edition

FT | UK edition

"Juristen geben Okay für Bankenabgabe" "Liberale bitten zur Kasse"

"Berlin und Paris bei Bankenabgabe einig"

"Bankenabgabe ruft Widerstand hervor"

"Hessen bleibt bei Bankenabgabe hart"

"14 Experten für das Großbanken-Problem"

"Obama nimmt Banken an die Kandarre"

"Finanzmarktaufsicht will schärfere Gesetze"

"Schärfere Vorschriften für Großbanken"

"Großbanken brauchen Kapital"

"Erleichterte Banken"

"Strengeres Regime für UBS und Credit Suisse"

"Der Schweizer Finma steht eine Juristin vor"

"Heikler Umgang mit den Großbanken" "Banken begrüßen Klärung"

$\begin{array}{cc}\text { FTD } & \text { 09-Mar-10 } \\ \text { FTD } & \text { 22-Mar-10 } \\ \text { BÖZ | edition 63 } & \text { 01-Apr-10 } \\ \text { BÖZ | edition 163 } & \text { 26-Aug-10 } \\ \text { BÖZ | edition 225 } & \text { 20-Nov-10 }\end{array}$

NZZ | Swiss edition

22-Jan-10

NZZ | Swiss edition 24-Mar-10

NZZ | Swiss edition 23-Apr-10

NZZ | Swiss edition 09-Sep-10

NZZ | Swiss edition 14-Sep-10

NZZ | Swiss edition $\quad 05-O c t-10$

NZZ | Swiss edition 22-Dec-10

NZZ | Swiss edition 05-Apr-11

NZZ | Swiss edition 16-Jun-11

Large banks welcome new rules 
A.2 Abnormal Returns in the United States (D odd-Frank Act)

P-values in brackets; dependent variable: daily bank stock return (left panel) and first difference in CD S spreads (right panel)

\begin{tabular}{|c|c|c|c|c|c|c|c|c|c|c|c|}
\hline \multirow[b]{2}{*}{ Estimation window } & & \multicolumn{5}{|c|}{ Stock Retums } & \multicolumn{5}{|c|}{ CDSSpreads } \\
\hline & & & 80 & 140 & 80 & 80 & & 80 & 140 & 80 & 80 \\
\hline Dodd-Frank Adt & Date & $\begin{array}{c}\text { Average } \\
\text { Return }\end{array}$ & $\begin{array}{c}\text { Average } \\
\text { Abnormal } \\
\text { Return }\end{array}$ & $\begin{array}{c}\text { Average } \\
\text { Abnormal } \\
\text { Return }\end{array}$ & $\begin{array}{c}\text { Investment } \\
\text { vs. } \\
\text { Commercial }\end{array}$ & $\begin{array}{l}\text { Systemic vs. } \\
\text { Non- } \\
\text { Systemic }\end{array}$ & $\begin{array}{c}\text { Average } \\
\text { Return }\end{array}$ & $\begin{array}{c}\text { Average } \\
\text { Abnormal } \\
\text { Return }\end{array}$ & $\begin{array}{c}\text { Average } \\
\text { Abnormal } \\
\text { Return }\end{array}$ & $\begin{array}{c}\text { Investment } \\
\text { vs. } \\
\text { Commercial }\end{array}$ & $\begin{array}{c}\text { Systemic vs. } \\
\text { Non- } \\
\text { Systemic }\end{array}$ \\
\hline Blueprint of the reform bill presented by 0 bama & 17-Jun-09 & -2.670 & $\begin{array}{l}-1.378 \\
{[0.761]}\end{array}$ & $\begin{array}{l}-1.275 \\
{[0.769]}\end{array}$ & $\begin{array}{l}-0.175 \\
{[0.955]}\end{array}$ & $\begin{array}{l}-1.757 \\
{[0.550]}\end{array}$ & 8.836 & $\begin{array}{l}9.890 \\
{[0.608]}\end{array}$ & $\begin{array}{l}9.848 \\
{[0.61]}\end{array}$ & $\begin{array}{c}-7.607 \\
{[0.627]}\end{array}$ & $\begin{array}{l}-2.065 \\
{[0.879]}\end{array}$ \\
\hline G eithner calls for detailed living will plans & 02-Sep-09 & -1.033 & $\begin{array}{l}-0.413 \\
{[0.845]}\end{array}$ & $\begin{array}{l}-0.041 \\
{[0.991]}\end{array}$ & $\begin{array}{l}-0.516 \\
{[0.720]}\end{array}$ & $\begin{array}{l}-0.353 \\
{[0.813]}\end{array}$ & 2.060 & $\begin{array}{c}5.228 \\
{[0.609]}\end{array}$ & $\begin{array}{r}3.280 \\
{[0.831]}\end{array}$ & $\begin{array}{r}2.679 \\
{[0.675]}\end{array}$ & $\begin{array}{r}2.837 \\
{[0.736]}\end{array}$ \\
\hline Obama's Speech: Wall Street must change & 14-Sep-09 & 0.892 & $\begin{array}{c}0.835 \\
{[0.657]}\end{array}$ & $\begin{array}{c}0.708 \\
{[0.847]}\end{array}$ & $\begin{array}{c}0.384 \\
{[0.735]}\end{array}$ & $\begin{array}{c}-0.003 \\
{[0.807]}\end{array}$ & -0.342 & $\begin{array}{c}1.806 \\
{[0.815]}\end{array}$ & $\begin{array}{c}0.857 \\
{[0.956]}\end{array}$ & $\begin{array}{c}-1.516 \\
{[0.786]}\end{array}$ & $\begin{array}{c}-1.189 \\
{[0.876]}\end{array}$ \\
\hline Reform bill entered the house & 11-Dec-09 & 0.663 & $\begin{array}{c}0.418 \\
{[0.729]}\end{array}$ & $\begin{array}{c}0.415 \\
{[0.801]}\end{array}$ & $\begin{array}{l}-0.964 \\
{[0.289]}\end{array}$ & $\begin{array}{l}-1.187 \\
{[0.272]}\end{array}$ & -1.951 & $\begin{array}{l}-1.629 \\
{[0.769]}\end{array}$ & $\begin{array}{c}0.336 \\
{[0.963]}\end{array}$ & $\begin{array}{l}-3.336 \\
{[0.330]}\end{array}$ & $\begin{array}{l}-2.517 \\
{[0.586]}\end{array}$ \\
\hline O bama set to target banks with new fees & 12-Jan-10 & -1.624 & $\begin{array}{l}-0.536 \\
{[0.673]}\end{array}$ & $\begin{array}{l}-0.661 \\
{[0.617]}\end{array}$ & $\begin{array}{l}-1.551^{*} \\
{[0.056]}\end{array}$ & $\begin{array}{l}-2.525 * 5^{* *} \\
{[0.012]}\end{array}$ & -0.285 & $\begin{array}{r}0.170 \\
{[0.967]}\end{array}$ & $\begin{array}{r}0.666 \\
{[0.904]}\end{array}$ & $\begin{array}{r}0.068 \\
{[0.981]}\end{array}$ & $\begin{array}{l}-0.074 \\
{[0.984]}\end{array}$ \\
\hline O bama urges banks to take part in crisis costs & 15-Jan-10 & -2.187 & $\begin{array}{c}-0.386 \\
{[0.761]}\end{array}$ & $\begin{array}{c}-0.517 \\
{[0.695]}\end{array}$ & $\begin{array}{c}-0.481 \\
{[0.554]}\end{array}$ & $\begin{array}{c}-0.837 \\
{[0.407]}\end{array}$ & 6.709 & $\begin{array}{l}7.131 * \\
{[0.080]}\end{array}$ & $\begin{array}{c}7.660 \\
{[0.163]}\end{array}$ & $\begin{array}{c}-1.306 \\
{[0.651]}\end{array}$ & $\begin{array}{c}1.249 \\
{[0.736]}\end{array}$ \\
\hline - Anticipatory effect [-1] & 20-Jan-10 & 0.163 & $\begin{array}{l}3.126^{* *} \\
{[0.014]}\end{array}$ & $\begin{array}{l}3.023 * * \\
{[0.021]}\end{array}$ & $\begin{array}{l}-1.059 \\
{[0.197]}\end{array}$ & $\begin{array}{l}-0.340 \\
{[0.736]}\end{array}$ & 0.901 & $\begin{array}{l}1.370 \\
{[0.730]}\end{array}$ & $\begin{array}{l}1.882 \\
{[0.729]}\end{array}$ & $\begin{array}{c}0.211 \\
{[0.941]}\end{array}$ & $\begin{array}{r}1.203 \\
{[0.742]}\end{array}$ \\
\hline Announcement of the Volcker Rule & 21-Jan-10 & -3.060 & $\begin{array}{c}-0.074 \\
{[0.953]}\end{array}$ & $\begin{array}{c}-0.177 \\
{[0.982]}\end{array}$ & $\begin{array}{c}-3.357 * * * \\
{[0.000]}\end{array}$ & $\begin{array}{c}-2.944 * * * \\
{[0.004]}\end{array}$ & 7.773 & $\begin{array}{l}8.242^{* *} \\
{[0.036]}\end{array}$ & $\begin{array}{c}8.754 \\
{[0.107]}\end{array}$ & $\begin{array}{c}7.863 * * * \\
{[0.006]}\end{array}$ & $\begin{array}{l}7.82^{* *} \\
{[0.033]}\end{array}$ \\
\hline - Enlarged event window [0-1] & & -7.223 & $\begin{array}{c}-2.012 \\
{[0.261]}\end{array}$ & $\begin{array}{c}-2.161 \\
{[0.250]}\end{array}$ & $\begin{array}{c}-3.875^{* * *} \\
{[0.001]}\end{array}$ & $\begin{array}{c}-0.916 \\
{[0.530]}\end{array}$ & 15.970 & $\begin{array}{c}16.908 * * * \\
{[0.003]}\end{array}$ & $\begin{array}{c}17.932 * * \\
{[0.020]}\end{array}$ & $\begin{array}{c}5.289 \\
{[0.169]}\end{array}$ & $\begin{array}{c}4.022 \\
{[0.496]}\end{array}$ \\
\hline Dodd urges republicans not to dilute the reform & 14-Mar-10 & -0.085 & $\begin{array}{r}0.835 \\
{[0.495]}\end{array}$ & $\begin{array}{r}0.843 \\
{[0.495]}\end{array}$ & $\begin{array}{l}-0.598 \\
{[0.465]}\end{array}$ & $\begin{array}{l}-0.807 \\
{[0.317]}\end{array}$ & -0.650 & $\begin{array}{l}0.330 \\
{[0.929]}\end{array}$ & $\begin{array}{l}0.808 \\
{[0.870]}\end{array}$ & $\begin{array}{l}-0.587 \\
{[0.800]}\end{array}$ & $\begin{array}{r}0.038 \\
{[0.991]}\end{array}$ \\
\hline Obama promoted reform plans in New Y ork City & 22-Apr-10 & 0.259 & $\begin{array}{l}0.466 \\
0.0669\end{array}$ & $\begin{array}{r}0.762 \\
0\end{array}$ & $\begin{array}{l}-0.136 \\
-00747\end{array}$ & $\begin{array}{l}0.216 \\
0.2641\end{array}$ & 5.103 & $\begin{array}{l}5.421 \\
{[0.115]}\end{array}$ & $\begin{array}{c}5.526 \\
{[0.168]}\end{array}$ & $\begin{array}{l}-0.676 \\
{[0.749]}\end{array}$ & $\begin{array}{l}0.275 \\
{[0.930]}\end{array}$ \\
\hline - Enlarged event window [0-1] & & 0.141 & -0.333 & -0.064 & $\begin{array}{l}{[.0 / 4]} \\
-0.377 \\
-0791\end{array}$ & -1.42 & 3.866 & $\begin{array}{l}8.368^{*} \\
{[0.087]}\end{array}$ & 8.578 & $\begin{array}{l}2.727 \\
\end{array}$ & $\begin{array}{r}3.526 \\
104266\end{array}$ \\
\hline D emocrats are willing to dilute rules for swap desks & 16-May-10 & -0.206 & $\begin{array}{c}{[0.829]} \\
0.371 \\
{[0.736]}\end{array}$ & $\begin{array}{c}{[0.969]} \\
0.653 \\
{[0.590]}\end{array}$ & $\begin{array}{c}{[0.767]} \\
0.206 \\
{[0.825]}\end{array}$ & $\begin{array}{l}{[0.163]} \\
-0.800 \\
{[0.328]}\end{array}$ & 4.436 & $\begin{array}{c}{[0.087]} \\
0.624 \\
{[0.913]}\end{array}$ & $\begin{array}{c}{[0.131]} \\
0.573 \\
{[0.910]}\end{array}$ & $\begin{array}{l}{[0.413]} \\
-5.83^{* *} \\
{[0.021]}\end{array}$ & $\begin{array}{l}{[0.426]} \\
-5.155 \\
{[0.154]}\end{array}$ \\
\hline - Anticipatory effect [-1] & 19-May-10 & 0.564 & $\begin{array}{c}1.454 \\
{[0.181]}\end{array}$ & $\begin{array}{c}1.738 \\
{[0.152]}\end{array}$ & $\begin{array}{c}1.310 \\
{[0.157]}\end{array}$ & $\begin{array}{l}-1.188 \\
{[0.293]}\end{array}$ & 4.762 & $\begin{array}{c}4.791 \\
{[0.397]}\end{array}$ & $\begin{array}{c}4.809 \\
{[0.334]}\end{array}$ & $\begin{array}{l}-5.22^{*} \\
{[0.067]}\end{array}$ & $\begin{array}{l}-4.821 \\
{[0.220]}\end{array}$ \\
\hline Reform bill passes the senate & 20-May-10 & -4.432 & $\begin{array}{l}-1.188 \\
{[0.635]}\end{array}$ & $\begin{array}{c}-0.691 \\
{[0.685]}\end{array}$ & $\begin{array}{c}0.317 \\
{[0.199]}\end{array}$ & $\begin{array}{l}-0.135 \\
{[0.504]}\end{array}$ & 10.353 & $\begin{array}{c}10.382 * * \\
{[0.226]}\end{array}$ & $\begin{array}{c}10.394 * * \\
{[0.152]}\end{array}$ & $\begin{array}{c}1.962 \\
{[0.433]}\end{array}$ & $\begin{array}{c}3.109 \\
{[0.996]}\end{array}$ \\
\hline Banks set to lose lobby fight on swaps & 13-Jun-10 & -0.121 & $\begin{array}{l}-2.2080^{* *} \\
-0.037]\end{array}$ & $\begin{array}{l}-2.186^{*} \\
-0.0647\end{array}$ & $\begin{array}{l}-0.330 \\
{[0.719]}\end{array}$ & $\begin{array}{r}-0.825 \\
-0.345]\end{array}$ & -8.985 & $\begin{array}{l}-5.797 \\
{[0.362]}\end{array}$ & $\begin{array}{l}-5.607 \\
{[0.299]}\end{array}$ & $\begin{array}{r}0.805 \\
{[0.7111}\end{array}$ & $\begin{array}{r}3.534 \\
{[0.312]}\end{array}$ \\
\hline Consensuns between parties - the dilution - & 25-Jun-10 & 2.825 & $\begin{array}{l}2.74 * * * \\
{[0.009]}\end{array}$ & $\begin{array}{l}2.796 * * \\
{[0.014]}\end{array}$ & $\begin{array}{c}0.890 \\
{[0.325]}\end{array}$ & $\begin{array}{c}-0.105 \\
{[0.895]}\end{array}$ & -4.307 & $\begin{array}{l}-4.514 \\
{[0.489]}\end{array}$ & $\begin{array}{l}-4.532 \\
{[0.404]}\end{array}$ & $\begin{array}{l}-2.674 \\
{[0.714]}\end{array}$ & $\begin{array}{l}-2.628 \\
{[0.571]}\end{array}$ \\
\hline Required votes for the bill achieved & 12-Jul-10 & 0.058 & $\begin{array}{c}1.306 \\
{[0.194]}\end{array}$ & $\begin{array}{c}1.505 \\
{[0.171]}\end{array}$ & $\begin{array}{c}0.577 \\
{[0.516]}\end{array}$ & $\begin{array}{c}0.065 \\
{[0.395]} \\
{[0.05}\end{array}$ & -3.327 & $\begin{array}{l}-8.790 \\
{[0.171]}\end{array}$ & $\begin{array}{l}-8.930 \\
{[0.143]}\end{array}$ & $\begin{array}{c}-3.371 \\
{[0.346]}\end{array}$ & $\begin{array}{c}0.304 \\
{[0.946]}\end{array}$ \\
\hline Dodd-Frank Act signed by Obama & 21-Jul-10 & -0.918 & $\begin{array}{c}0.130 \\
{[0.908]}\end{array}$ & $\begin{array}{c}0.228 \\
{[0.833]}\end{array}$ & $\begin{array}{l}1.638^{*} \\
{[0.057]}\end{array}$ & $\begin{array}{c}0.164 \\
{[0.828]}\end{array}$ & -0.935 & $\begin{array}{c}-0.087 \\
{[0.989]}\end{array}$ & $\begin{array}{c}-0.012 \\
{[0.982]}\end{array}$ & $\begin{array}{c}-0.262 \\
{[0.963]}\end{array}$ & $\begin{array}{c}0.567 \\
{[0.898]}\end{array}$ \\
\hline
\end{tabular}

Notes: The table shows the results from SUR regressions corresponding to the subevents for stock returns and CD spreads, respectively, using estimation windows of 80 or 140 trading days. Each system of regressions includes 10 banks. All subevents refer to frontpage articles in the Financial Times, U.S. edition. The number of observations ranges between 800 (corresponding to an estimation window of 80 days) and 1400 ( 140 trading days). All estimations are using balanced samples. If the estimation window contains another subevent, this is "dummied out" by including the corresponding event dummies (including pre-
and post-event dummies). Through an iteration procedure, we make sure that all estimation windows contain exactly the given number of observations (not including other events). The regressions in the left panel the unadjusted average return of all banks within the sample at the respective event day. "Average Abnormal Returns" refer to the average abuds (in basis points). The first number column in each panel displajs "Investment vs. Commercial" shows the difference in abnormal returns of investment banks and commercial banks. The splitting is based on customer deposits as a share of total assets and non-interest income a a share of total revenue. The column "Systemic vs. Non-Systemic" displays the difference in abnormal returns of systemically relevant and non-systemically relevant banks. The latter selection is based on the list of 29 systemically relevant institutions, published by the Financial Stability Board on 4 th November 2011 . The tests for heterogeneity are conducted on the basis of an 80 trading days estimation window. The pdummies in order to account for anticipation effects. The results for an enlarged event window of two days are displayed only if the average cumulated abnormal returns are statistically significant. Stars are to be interpreted as follows: *** significant at 1 percent, ** significant at 5 percent, * significant at 10 percent. 
A.3. Abnormal Returns in the United Kingdom (The Vickers Reform Proposals)

P-values in brackets; dependent variable: daily bank stock retum (left panel) and first difference in CD S spreads (right panel)

\begin{tabular}{|c|c|c|c|c|c|c|c|c|c|c|c|}
\hline \multirow[b]{2}{*}{ Estimation window } & & \multicolumn{5}{|c|}{ Stock Retums } & \multicolumn{5}{|c|}{ CDS Spreads } \\
\hline & & & 80 & 140 & 80 & 80 & & 80 & 140 & 80 & 80 \\
\hline The Vickers Reform Proposals & Date & $\begin{array}{l}\text { Average } \\
\text { Retur }\end{array}$ & $\begin{array}{c}\text { Average } \\
\text { Abnommal } \\
\text { Returm }\end{array}$ & $\begin{array}{c}\text { Average } \\
\text { Abnommal } \\
\text { Return }\end{array}$ & $\begin{array}{l}\text { Investment } \\
\text { vs. } \\
\text { Commercial }\end{array}$ & $\begin{array}{l}\text { Systemic } \\
\text { vs. Non- } \\
\text { Systemic }\end{array}$ & $\begin{array}{l}\text { Average } \\
\text { Return }\end{array}$ & $\begin{array}{c}\text { Average } \\
\text { Abnormal } \\
\text { Retum }\end{array}$ & $\begin{array}{c}\text { Average } \\
\text { Abnommal } \\
\text { Return }\end{array}$ & $\begin{array}{l}\text { Investment vs. } \\
\text { Commercial }\end{array}$ & $\begin{array}{c}\text { Systemic vs. } \\
\text { Non- } \\
\text { Systemic }\end{array}$ \\
\hline - Anticipatory effect [-1] & 20-Jan-10 & -2.185 & $\begin{array}{c}-2.255 \\
{[0.285]}\end{array}$ & $\begin{array}{c}-2.546 \\
{[0.237]}\end{array}$ & $\begin{array}{c}0.021 \\
{[0.990]}\end{array}$ & $\begin{array}{c}1.526 \\
{[0.372]}\end{array}$ & 5.786 & $\begin{array}{c}5.748^{* * *} \\
{[0.005]}\end{array}$ & $\begin{array}{l}6.142^{* *} \\
{[0.019]}\end{array}$ & $\begin{array}{c}0.254 \\
{[0.884]}\end{array}$ & $\begin{array}{c}-1.803 \\
{[0.430]}\end{array}$ \\
\hline Spillover effect: Announcement of the Volcker Rule & 21-Jan-10 & -5.010 & $\begin{array}{c}-4.801 * * \\
{[0.022]}\end{array}$ & $\begin{array}{c}-5.141 * * \\
{[0.016]}\end{array}$ & $\begin{array}{l}-2.246 \\
{[0.202]}\end{array}$ & $\begin{array}{c}0.527 \\
{[0.757]}\end{array}$ & 1.978 & $\begin{array}{c}1.940 \\
{[0.344]}\end{array}$ & $\begin{array}{c}2.334 \\
{[0.372]}\end{array}$ & $\begin{array}{c}0.842 \\
{[0.628]}\end{array}$ & $\begin{array}{c}2.349 \\
{[0.304]}\end{array}$ \\
\hline Appointing the Vickers Commission & 16-Jun-10 & 0.667 & $\begin{array}{c}0.383 \\
{[0.875]}\end{array}$ & $\begin{array}{c}0.349 \\
{[0.878]}\end{array}$ & $\begin{array}{c}-0.015 \\
{[0.991]}\end{array}$ & $\begin{array}{l}-1.321 \\
{[0.403]}\end{array}$ & 3.544 & $\begin{array}{c}3.212 \\
{[0.656]}\end{array}$ & $\begin{array}{c}3.134 \\
{[0.571]}\end{array}$ & $\begin{array}{c}0.456 \\
{[0.930]}\end{array}$ & $\begin{array}{c}4.238 \\
{[0.567]}\end{array}$ \\
\hline Spillover effect: Consensuns between parties - the dilution - & 25-Jun-10 & -0.961 & $\begin{array}{l}-1.363 \\
{[0.558]}\end{array}$ & $\begin{array}{l}-1.362 \\
{[0.539]}\end{array}$ & $\begin{array}{c}1.175 \\
{[0.202]}\end{array}$ & $\begin{array}{l}-3.489 * * \\
{[0.021]}\end{array}$ & 2.132 & $\begin{array}{c}2.017 \\
{[0.766]}\end{array}$ & $\begin{array}{c}1.823 \\
{[0.734]}\end{array}$ & $\begin{array}{c}2.825 \\
{[0.566]}\end{array}$ & $\begin{array}{c}2.678 \\
{[0.700]}\end{array}$ \\
\hline - Anticipatory effect [-1] & 04-Aug-10 & -0.453 & $\begin{array}{c}-0.619 \\
{[0.809]}\end{array}$ & $\begin{array}{c}-0.813 \\
{[0.722]}\end{array}$ & $\begin{array}{c}0.056 \\
{[0.971]}\end{array}$ & $\begin{array}{c}5.939 * * * \\
{[0.000]}\end{array}$ & -0.800 & $\begin{array}{c}-0.955 \\
{[0.894]}\end{array}$ & $\begin{array}{c}-0.084 \\
{[0.880]}\end{array}$ & $\begin{array}{l}-2.004 \\
{[0.705]}\end{array}$ & $\begin{array}{c}1.601 \\
{[0.830]}\end{array}$ \\
\hline Barclays warns to levae U.K. in case of a bank break-up & 05-Aug-10 & -0.669 & $\begin{array}{c}-0.833 \\
{[0.745]}\end{array}$ & $\begin{array}{l}-1.025 \\
{[0.654]}\end{array}$ & $\begin{array}{c}-3.004 * * \\
{[0.0488}\end{array}$ & $\begin{array}{l}-0.668 \\
{[0.658]}\end{array}$ & 4.150 & $\begin{array}{l}3.995 \\
{[0.576]}\end{array}$ & $\begin{array}{c}4.056 \\
{[0.495]}\end{array}$ & $\begin{array}{c}4.571 \\
{[0.388]}\end{array}$ & $\begin{array}{r}5.239 \\
{[0.483]}\end{array}$ \\
\hline Vickers tends to split up big banks & 18-Jan-11 & 0.743 & $\begin{array}{c}0.801 \\
{[0.588]}\end{array}$ & $\begin{array}{c}0.703 \\
{[0.675]}\end{array}$ & $\begin{array}{c}0.351 \\
{[0.769]}\end{array}$ & $\begin{array}{l}-0.888 \\
{[0.545]}\end{array}$ & -3.310 & $\begin{array}{l}-3.451 \\
{[0.292]}\end{array}$ & $\begin{array}{c}-3.066 \\
{[0.313]}\end{array}$ & $\begin{array}{c}-0.263 \\
{[0.889]}\end{array}$ & $\begin{array}{l}-4.454 \\
{[0.157]}\end{array}$ \\
\hline Big banks filed petitions for not splitting up banks & 26-Jan-11 & -1.011 & $\begin{array}{c}-0.660 \\
{[0.680]}\end{array}$ & $\begin{array}{l}-1.292 \\
{[0.466]}\end{array}$ & $\begin{array}{l}-1.802 \\
{[0.180]}\end{array}$ & $\begin{array}{l}-1.690 \\
{[0.297]}\end{array}$ & -0.601 & $\begin{array}{c}-0.567 \\
{[0.858]}\end{array}$ & $\begin{array}{c}-0.336 \\
{[0.915]}\end{array}$ & $\begin{array}{l}4.271 * * \\
{[0.023]}\end{array}$ & $\begin{array}{l}5.386^{*} \\
{[0.080]}\end{array}$ \\
\hline Osbome backs higher capital requirements for banks & 06-Mar-11 & -0.836 & $\begin{array}{l}-1.094 \\
{[0.424]}\end{array}$ & $\begin{array}{l}-1.112 \\
{[0.434]}\end{array}$ & $\begin{array}{c}0.164 \\
{[0.895]}\end{array}$ & $\begin{array}{c}-0.258 \\
{[0.857]}\end{array}$ & 2.254 & $\begin{array}{c}2.042 \\
{[0.508]}\end{array}$ & $\begin{array}{c}2.260 \\
{[0.437]}\end{array}$ & $\begin{array}{c}1.108 \\
{[0.590]}\end{array}$ & $\begin{array}{c}2.070 \\
{[0.505]}\end{array}$ \\
\hline Senior Whitehall officials push for peace deal with banks & 30-Mar-11 & -0.838 & $\begin{array}{c}-0.877 \\
{[0.507]}\end{array}$ & $\begin{array}{l}-0.939 \\
{[0.484]}\end{array}$ & $\begin{array}{c}-0.985 \\
{[0.390]}\end{array}$ & $\begin{array}{l}-1.659 \\
{[0.218]}\end{array}$ & 1.515 & $\begin{array}{c}1.428 \\
{[0.568]}\end{array}$ & $\begin{array}{c}1.565 \\
{[0.599]}\end{array}$ & $\begin{array}{c}1.235 \\
{[0.558]}\end{array}$ & $\begin{array}{c}0.009 \\
{[0.998]}\end{array}$ \\
\hline Osbome welcomes banks reforms & 08-Apr-11 & 0.460 & $\begin{array}{c}0.447 \\
{[0.741]}\end{array}$ & $\begin{array}{c}0.006 \\
{[0.673]}\end{array}$ & $\begin{array}{c}0.552 \\
{[0.646]}\end{array}$ & $\begin{array}{c}-0.195 \\
{[0.892]}\end{array}$ & -3.319 & $\begin{array}{c}-2.895 \\
{[0.387]}\end{array}$ & $\begin{array}{l}-3.174 \\
{[0.307]}\end{array}$ & $\begin{array}{l}-1.952 \\
{[0.396]}\end{array}$ & $\begin{array}{c}-2.943 \\
{[0.424]}\end{array}$ \\
\hline Equity requirements proposal (better than expected) & 11-Apr-11 & 0.799 & $\begin{array}{c}0.621 \\
{[0.632]}\end{array}$ & $\begin{array}{c}0.594 \\
{[0.659]}\end{array}$ & $\begin{array}{l}2.693^{* *} \\
{[0.014]}\end{array}$ & $\begin{array}{c}1.827 \\
{[0.177]}\end{array}$ & -1.415 & $\begin{array}{l}-1.255 \\
{[0.703]}\end{array}$ & $\begin{array}{l}-1.221 \\
{[0.684]}\end{array}$ & $\begin{array}{c}-0.329 \\
{[0.875]}\end{array}$ & $\begin{array}{c}-0.945 \\
{[0.771]}\end{array}$ \\
\hline Fear that foreign banks take advantage of tough UK regulation & 17-Apr-11 & -2.231 & $\begin{array}{c}-0.425 \\
{[0.741]}\end{array}$ & $\begin{array}{l}-0.444 \\
{[0.740]}\end{array}$ & $\begin{array}{l}-1.450 \\
{[0.180]}\end{array}$ & $\begin{array}{l}-1.037 \\
{[0.438]}\end{array}$ & 9.109 & $\begin{array}{c}9.431^{* * *} \\
{[0.003]}\end{array}$ & $\begin{array}{c}9.312^{* * *} \\
{[0.002]}\end{array}$ & $\begin{array}{l}4.625^{* *} \\
{[0.024]}\end{array}$ & $\begin{array}{c}3.408 \\
{[0.291]}\end{array}$ \\
\hline Osbome's pre-approval of the ringfencing approach & 15-Jun-11 & -1.743 & $\begin{array}{l}-1.600 \\
{[0.144]}\end{array}$ & $\begin{array}{l}-1.667 \\
{[0.189]}\end{array}$ & $\begin{array}{c}-0.943 \\
{[0.279]}\end{array}$ & $\begin{array}{c}-0.630 \\
{[0.587]}\end{array}$ & 4.391 & $\begin{array}{l}4.248^{*} \\
{[0.085]}\end{array}$ & $\begin{array}{c}4.251 \\
{[0.138]}\end{array}$ & $\begin{array}{c}1.320 \\
{[0.477]}\end{array}$ & $\begin{array}{c}3.652 \\
{[0.105]}\end{array}$ \\
\hline - Anticipatory effect [-1] & 30-Aug-11 & 6.200 & $\begin{array}{l}6.773^{*} \\
{[0.06]}\end{array}$ & $\begin{array}{c}6.555 * * * \\
{[0.001]}\end{array}$ & $\begin{array}{c}2.140 \\
{[0.186]}\end{array}$ & $\begin{array}{c}2.789 \\
{[0.133]}\end{array}$ & 0.864 & $\begin{array}{c}-0.503 \\
{[0.916]}\end{array}$ & $\begin{array}{c}0.228 \\
{[0.954]}\end{array}$ & $\begin{array}{c}-2.259 \\
{[0.434]}\end{array}$ & $\begin{array}{c}-2.699 \\
{[0.402]}\end{array}$ \\
\hline Postponement of the reform to 2015 (post-election period) & 31-Aug-11 & 3.164 & $\begin{array}{c}-3.983 \\
{[0.110]}\end{array}$ & $\begin{array}{l}3.766^{*} \\
{[0.055]}\end{array}$ & $\begin{array}{c}0.317 \\
{[0.847]}\end{array}$ & $\begin{array}{c}1.005 \\
{[0.594]}\end{array}$ & -8.649 & $\begin{array}{c}-10.011^{* *} \\
{[0.036]}\end{array}$ & $\begin{array}{c}-9.286 * * \\
{[0.019]}\end{array}$ & $\begin{array}{c}-8.07 * * * * \\
{[0.005]}\end{array}$ & $\begin{array}{l}-5.32^{*} \\
{[0.099]}\end{array}$ \\
\hline - Enlarged event window [0-1] & & 7.366 & $\begin{array}{l}8.972 * * \\
{[0.013]}\end{array}$ & $\begin{array}{c}8.538 * * * \\
{[0.002]}\end{array}$ & $\begin{array}{l}5.408^{* *} \\
{[0.022]}\end{array}$ & $\begin{array}{l}5.879 * * \\
{[0.030]}\end{array}$ & -14.991 & $\begin{array}{c}-17.73^{* * *} \\
{[0.009]}\end{array}$ & $\begin{array}{c}-16.27 * * * \\
{[0.004]}\end{array}$ & $\begin{array}{c}-14.246 * * * \\
{[0.001]}\end{array}$ & $\begin{array}{l}-9.069 * * \\
{[0.046]}\end{array}$ \\
\hline - Anticipatory effect [-1] & 09-Sep-11 & -5.541 & $\begin{array}{l}-4.941 * * \\
{[0.045]}\end{array}$ & $\begin{array}{c}-5.161 * * * \\
{[0.009]}\end{array}$ & $\begin{array}{c}-3.814^{*} \\
{[0.057]}\end{array}$ & $\begin{array}{c}-1.719 \\
{[0.342]}\end{array}$ & 11.557 & $\begin{array}{c}10.157 * * \\
{[0.033]}\end{array}$ & $\begin{array}{c}10.873^{* * *} \\
{[0.006]}\end{array}$ & $\begin{array}{l}-1.602 \\
{[0.575]}\end{array}$ & $\begin{array}{c}1.260 \\
{[0.690]}\end{array}$ \\
\hline Publication of the Vickers Report & 12-Sep-11 & -1.547 & $\begin{array}{l}-1.120 \\
{[0.657]}\end{array}$ & $\begin{array}{c}-1.369 \\
{[0.495]}\end{array}$ & $\begin{array}{c}-0.317 \\
{[0.847]}\end{array}$ & $\begin{array}{c}-2.756 \\
{[0.138]}\end{array}$ & 15.138 & $\begin{array}{c}13.738 * * * \\
{[0.004]}\end{array}$ & $\begin{array}{c}14.455 * * * \\
{[0.000]}\end{array}$ & $\begin{array}{c}2.493 \\
{[0.382]}\end{array}$ & $\begin{array}{l}5.633^{*} \\
{[0.075]}\end{array}$ \\
\hline
\end{tabular}

Notes: The table shows the results from SUR regressions corresponding to the subevents for stock returns and CD S spreads, respectively, using estimation windows of 80 or 140 trading days. Each system of regressions days). All estimations are using balanced samples. If the estimation window contains another subevent, this is "dummied out" by including the corresponding event dummies (including pre- and post-event dummies). Through an iteration procedure, we make sure that all estimation windows contain exactly the given number of observations (not including other events). The regressions in the left panel use daily stock returns of banks as dependent variable (in percentage points), those in the right panel use daily first differences in bank CDS spreads (in basis points). The first number column in each panel displays the unadjusted average returm of all banks within the sample at the respective event day. "Average Abnomal Returns" refer to the average abnormal return of all banks at the respective event day. The Collumn "lnvestment vs. Come The coll shows he difference in abnormal retums of investment banks and commercial banks. The splitting is based on customer deposits as a share of total assets and non-interest income as a share of total revenue. The column "Systemic vs. NonStability Board on 4th November 2011. The tests for heterogeneity are conducted on the basis of an 80 trading days estimation window. The $p$-values in brackets correspond to the tests whether the average abnormal retums and the difference in abnormal returns between the two given bank groups is equal to zero. All regressions include pre-event dummies in order to account for anticipation effects. The results for an enlarged event window of two days are displayed only if the average cumulated abnormal returns are statistically significant. Stars are to be interpreted as follows: *** significant at 1 percent, ** significant at 5 percent, * significant at 10 percent. 
A.4. Abnormal Returns in G ermany (Bank Tax and Restructuring-Law)

P-Values in brackets; dependent variable: daily bank stock return (left panel) and first difference in CD S spreads (right panel)

\begin{tabular}{|c|c|c|c|c|c|c|c|c|c|}
\hline \multirow[b]{2}{*}{ Estimation window } & & & \multicolumn{3}{|c|}{ StockRetums } & \multicolumn{3}{|c|}{ CDSSpreads } & \multirow[b]{2}{*}{80} \\
\hline & & & 80 & 140 & 80 & & 80 & 140 & \\
\hline Bank Tax and Restructuning-Law & Date & $\begin{array}{c}\text { Average } \\
\text { Return }\end{array}$ & $\begin{array}{c}\text { Average } \\
\text { Abnormal } \\
\text { Return }\end{array}$ & $\begin{array}{c}\text { Average } \\
\text { Abnormal } \\
\text { Return }\end{array}$ & $\begin{array}{l}\text { Systemic vs. } \\
\text { Non- } \\
\text { Systemic }\end{array}$ & $\begin{array}{l}\text { Average } \\
\text { Return }\end{array}$ & $\begin{array}{c}\text { Average } \\
\text { Abnormal } \\
\text { Return }\end{array}$ & $\begin{array}{c}\text { Average } \\
\text { Abnormal } \\
\text { Return }\end{array}$ & $\begin{array}{l}\text { Systemic vs. } \\
\text { Non-Systemic }\end{array}$ \\
\hline Constitutional experts: A Bank Tax is juridical feasible & 08-Mar-10 & -0.733 & $\begin{array}{l}-0.661 \\
{[0.740]}\end{array}$ & $\begin{array}{c}-1.004 \\
{[0.670]}\end{array}$ & $\begin{array}{c}0.799 \\
{[0.579]}\end{array}$ & -4.234 & $\begin{array}{c}-4.080 \\
{[0.101]}\end{array}$ & $\begin{array}{c}-3.880 \\
{[0.163]}\end{array}$ & $\begin{array}{c}3.416 \\
{[0.238]}\end{array}$ \\
\hline Governing coalition urges for Bank Tax & 21-Mar-10 & -0.613 & $\begin{array}{l}-0.436 \\
{[0.824]}\end{array}$ & $\begin{array}{l}-0.704 \\
{[0.763]}\end{array}$ & $\begin{array}{c}0.929 \\
{[0.515]}\end{array}$ & 3.736 & $\begin{array}{c}3.594 \\
{[0.149]}\end{array}$ & $\begin{array}{c}4.124 \\
{[0.120]}\end{array}$ & $\begin{array}{c}0.769 \\
{[0.756]}\end{array}$ \\
\hline Key points for Bank Tax and Restructuring-Law agreed by the cabinet & 31-Mar-10 & -0.100 & $\begin{array}{l}-0.102 \\
{[0.954]}\end{array}$ & $\begin{array}{l}-0.253 \\
{[0.913]}\end{array}$ & $\begin{array}{l}-1.476 \\
{[0.294]}\end{array}$ & 2.350 & $\begin{array}{c}2.309 \\
{[0.266]}\end{array}$ & $\begin{array}{c}2.462 \\
{[0.212]}\end{array}$ & $\begin{array}{l}4.775 * * \\
{[0.014]}\end{array}$ \\
\hline Bank Tax and Restructuring-Law passed by the federal cabinet & 25-Aug-10 & -1.585 & $\begin{array}{l}-1.524 \\
{[0.392]}\end{array}$ & $\begin{array}{l}-1.596 \\
{[0.348]}\end{array}$ & $\begin{array}{l}-0.533 \\
{[0.687]}\end{array}$ & 2.830 & $\begin{array}{c}2.588 \\
{[0.704]}\end{array}$ & $\begin{array}{c}2.640 \\
{[0.628]}\end{array}$ & $\begin{array}{l}-1.777 \\
{[0.671]}\end{array}$ \\
\hline Threat to call the mediation committee - one state blocks the bill & 19-Nov-10 & -0.022 & $\begin{array}{l}-0.135 \\
{[0.908]}\end{array}$ & $\begin{array}{c}0.007 \\
{[0.996]}\end{array}$ & $\begin{array}{l}-2.148 \\
{[0.157]}\end{array}$ & 3.510 & $\begin{array}{c}3.572 \\
{[0.384]}\end{array}$ & $\begin{array}{c}3.431 \\
{[0.560]}\end{array}$ & $\begin{array}{l}-2.175 \\
{[0.664]}\end{array}$ \\
\hline
\end{tabular}

Notes: The table shows the results from SUR regressions corresponding to the subevents for stock returns and CD S spreads, respectively, using estimation windows of 80 or 140 trading days. Each system of regressions includes 5 banks. All subevents refer to frontpage articles, either in the in the Financial Times Deutschland, (FTD) or the Börsenzeitung. The number of observations ranges between 400 (corresponding to an estimation window of 80 days) and 700 (140 trading days). All estimations are using balanced samples. If the estimation window contains another subevent, this is "dummied out" by including the corresponding event dummies (including pre- and post-event dummies). Through an iteration procedure, we make sure that all estimation windows contain exactly the given number of observations (not including other events). The regressions in the left panel use daily stock returns of banks as dependent variable (in percentage points), those in the right panel use daily first differences in bank CD S spreads (in basis points). The first number column in each panel displays the unadjusted average return of all banks within the sample at the respective event day. "Average Abnormal Returns" refer to the average abnormal return of all banks at the respective event day. The column "Systemic vs. Non-Systemic" displays the difference in abnormal returns of systemically relevant and non-systemically relevant banks. The selection is based on the list of 29 systemically relevant institutions, published by the Financial Stability Board on 4th November 2011. The tests for heterogeneity are conducted on the basis of an 80 trading days estimation window. The p-values in brackets correspond to the tests whether the average abnormal returns and the difference in abnormal returns between the two given bank groups is equal to zero. All regressions include pre-event dummies in order to account for anticipation effects. The results for an enlarged event window of two days are displayed only if the average cumulated abnormal returns are statistically significant. Stars are to be interpreted as follows: *** significant at 1 percent, ** significant at 5 percent, * significant at 10 percent. 
A.5. Abnormal Returns in Switzerland (Too-Big-To-Fail-Regulation)

P-values in brackets; dependent variable: daily bank stock return (left panel) and first difference in CD S spreads (right panel)

\begin{tabular}{|c|c|c|c|c|c|c|c|c|}
\hline \multirow[b]{2}{*}{ Estimation window } & & \multicolumn{4}{|c|}{ Stock Retums } & \multicolumn{3}{|c|}{ CDSSpreads } \\
\hline & & & 80 & 140 & 80 & & 80 & 140 \\
\hline Too-big-to-fail-Regulation & Date & $\begin{array}{l}\text { Average } \\
\text { Return }\end{array}$ & $\begin{array}{l}\text { Average abnormal } \\
\text { Return }\end{array}$ & $\begin{array}{c}\text { Average } \\
\text { abnormal Return }\end{array}$ & $\begin{array}{l}\text { Systemic vs. } \\
\text { Non-Systemic }\end{array}$ & $\begin{array}{l}\text { Average } \\
\text { Return }\end{array}$ & $\begin{array}{l}\text { Avergae abnormal A } \\
\text { Return }\end{array}$ & $\begin{array}{l}\text { Avergae abnormal } \\
\text { Return }\end{array}$ \\
\hline - Anticipatory effect [-1] & 03-Nov-09 & -0.013 & $-1.884^{* *}$ & $-1.893^{*}$ & $-3.209^{*}$ & & & \\
\hline Appointment of the too-big-to-fail-comission & 04-Nov-09 & 1.601 & $\begin{array}{c}{[0.036]} \\
1.242 \\
{[0.213]}\end{array}$ & $\begin{array}{c}{[0.073]} \\
1.253 \\
{[0.259]}\end{array}$ & $\begin{array}{c}{[0.081]} \\
0.741 \\
{[0.718]}\end{array}$ & n.a. & n.a. & n.a. \\
\hline Spillover-Effect: Announcement of the Volcker Rule & 21-Jan-10 & -0.333 & $\begin{array}{c}-1.346^{* *} \\
{[0.043]}\end{array}$ & $\begin{array}{l}-1.494^{*} \\
{[0.052]}\end{array}$ & $\begin{array}{c}-4.54^{* * *} \\
{[0.006]}\end{array}$ & 1.255 & $\begin{array}{c}1.665 \\
{[0.612]}\end{array}$ & $\begin{array}{c}2.176 \\
{[0.619]}\end{array}$ \\
\hline Financial Market Supervision (FINMA) claims law on large banks & 23-Mar-10 & -0.033 & $\begin{array}{l}-0.566 \\
{[0.414]}\end{array}$ & $\begin{array}{c}-0.679 \\
{[0.409]}\end{array}$ & $\begin{array}{c}1.113 \\
{[0.465]}\end{array}$ & -2.849 & $\begin{array}{l}-2.949 \\
{[0.339]}\end{array}$ & $\begin{array}{l}-2.669 \\
{[0.436]}\end{array}$ \\
\hline - Anticipatory effect [-1] & 21-Apr-10 & & $\begin{array}{c}0.182 \\
{[0.789]}\end{array}$ & $\begin{array}{c}0.046 \\
{[0.953]}\end{array}$ & $\begin{array}{l}-1.221 \\
{[0.431}\end{array}$ & 8.670 & $\begin{array}{c}8.994 * * * \\
{[0.001]}\end{array}$ & $\begin{array}{c}8.953 * * * \\
{[0.007]}\end{array}$ \\
\hline Press conference on preliminary too-big-to-fail-report & 22-Apr-10 & -1.199 & $\begin{array}{l}-0.959 \\
{[0.157]}\end{array}$ & $\begin{array}{l}-1.087 \\
{[0.158]}\end{array}$ & $\begin{array}{l}-2.067 \\
{[0.181]}\end{array}$ & 9.953 & $\begin{array}{c}9.994 * * * \\
{[0.002]}\end{array}$ & $\begin{array}{c}9.953 * * * \\
{[0.003]}\end{array}$ \\
\hline - Enlarged event window [0-1] & & -0.204 & $\begin{array}{c}0.036 \\
{[0.970]}\end{array}$ & $\begin{array}{l}-0.192 \\
{[0.861]}\end{array}$ & $\begin{array}{l}-0.142 \\
{[0.926]}\end{array}$ & 4.623 & $\begin{array}{l}9.487 * * \\
{[0.039]}\end{array}$ & $\begin{array}{l}9.406^{* *} \\
{[0.045]}\end{array}$ \\
\hline Big banks need more capital according to Basel III & 07-Sep-10 & -0.825 & $\begin{array}{l}-1.018 \\
{[0.373]}\end{array}$ & $\begin{array}{l}-1.304 \\
{[0.234]}\end{array}$ & $\begin{array}{l}-1.102 \\
{[0.549]}\end{array}$ & 2.790 & $\begin{array}{c}3.593 \\
{[0.624]}\end{array}$ & $\begin{array}{c}3.007 \\
{[0.644]}\end{array}$ \\
\hline Basel III comitte sets the equity requirements & 13-Sep-10 & 0.463 & $\begin{array}{c}0.353 \\
{[0.668]}\end{array}$ & $\begin{array}{c}0.272 \\
{[0.718]}\end{array}$ & $\begin{array}{c}1.617 \\
{[0.415]}\end{array}$ & -3.370 & $\begin{array}{c}-1.512 \\
{[0.894]}\end{array}$ & $\begin{array}{c}-3.493 \\
{[0.588]}\end{array}$ \\
\hline Press conference - presenting the final report & 04-Oct-10 & -0.693 & $\begin{array}{c}-0.390 \\
{[0.687]}\end{array}$ & $\begin{array}{l}-0.397 \\
{[0.651]}\end{array}$ & $\begin{array}{c}1.206 \\
{[0.517]}\end{array}$ & -3.220 & $\begin{array}{l}-3.550 \\
{[0.626]}\end{array}$ & $\begin{array}{l}-3.511 \\
{[0.584]}\end{array}$ \\
\hline Swiss federal council adopts draft of law for large banks & 21-Dec-10 & 0.505 & $\begin{array}{c}0.202 \\
{[0.691]}\end{array}$ & $\begin{array}{c}0.220 \\
{[0.738]}\end{array}$ & $\begin{array}{c}1.055 \\
{[0.506]}\end{array}$ & 0.815 & $\begin{array}{c}1.441 \\
{[0.740]}\end{array}$ & $\begin{array}{c}1.029 \\
{[0.875]}\end{array}$ \\
\hline D isagreement about application of equity requirements & 04-Apr-11 & -0.720 & $\begin{array}{c}-0.055 \\
{[0.897]}\end{array}$ & $\begin{array}{c}-0.022 \\
{[0.967]}\end{array}$ & $\begin{array}{c}-0.065 \\
{[0.959]}\end{array}$ & -2.287 & $\begin{array}{c}-2.500 \\
{[0.523]}\end{array}$ & $\begin{array}{c}-2.629 \\
{[0.490]}\end{array}$ \\
\hline Large banks welcome new rules & 15-Jun-11 & -1.029 & $\begin{array}{l}-0.306 \\
{[0.458]}\end{array}$ & $\begin{array}{c}-0.296 \\
{[0.481]}\end{array}$ & $\begin{array}{l}-1.112 \\
{[0.317]}\end{array}$ & -0.132 & $\begin{array}{l}-2.765 \\
{[0.401]}\end{array}$ & $\begin{array}{l}-2.722 \\
{[0.451]}\end{array}$ \\
\hline
\end{tabular}

Notes: The table shows the results from SUR regressions corresponding to the subevents for stock returns and CD S spreads, respectively, using estimation windows of 80 or 140 trading days. All subevents refer to frontpage articles in Neue Zürcher Zeitung (NZZ). In case of stock returns each system of regressions includes 8 banks. The number of observations for stock returns ranges between 640 (corresponding to an estimation window of 80 days) and 1120 (140 trading days). In case of CD S spreads each system of regressions includes 2 banks for reasons of availability. The number of observation s for CD S spreads ranges between 160 (corresponding to an estimation window of 80 days) and 280 (140 trading days). If the estimation window contains another subevent, this is "dummied out" by including the corresponding event dummies (including pre- and post-event dummies). Through an iteration procedure, we make sure that all estimation windows contain exactly the given number of observations (not including other events). The regressions in the left panel use daily stock returns of banks as dependent variable (in percentage points), those in the right panel use daily first differences in bank CD S spreads (in basis points). The first number column in each panel displays the unadjusted average return of all banks within the sample at the respective event day. "Average Abnormal Returns" refer to the average abnormal return of all banks at the respective event day. The column "Systemic vs. Non-Systemic" displays the difference in abnormal returns of systemically relevant and nonsystemically relevant banks. The latter selection is based on the list of 29 systemically relevant institutions, published by the Financial Stability Board on 4th November 2011. The tests for heterogeneity ame conducted on the basis of an 80 trading days estimation window. The p-values in brackets correspond to the tests whether the average abnormal returns and the difference in abnormal returns between the two given bank groups is equal to zero. All regressions include pre-event dummies in order to account for anticipation effects. The results for an enlarged event window of two days are displayed only if the average cumulated abnormal returns are statistically significant. Stars are to be interpreted as follows: *** significant at 1 percent, ${ }^{* *}$ significant at 5 percent, ${ }^{*}$ significant at 10 percent. 